\title{
West Palaearctic species of the genus Eloeophila (Diptera: Limoniidae)
}

\author{
JAROSLAV STARÝ \\ Department of Zoology and Laboratory of Ornithology, Faculty of Science of the Palacký University, \\ tř. Svobody 26, CZ-77146 Olomouc, Czech Republic; e-mail: stary@prfnw.upol.cz
}

Key words. Diptera, Limoniidae, Eloeophila, West Palaearctic, taxonomy, redescriptions, new synonymy, lectotype designation, new species, new records, distribution, key

\begin{abstract}
A review of West Palaearctic species of the genus Eloeophila Rondani, 1856 is presented. Three species are redescribed, viz. E. czernyi (Strobl in Czerny \& Strobl, 1909), E. laciniata (Edwards, 1928), and E. pusilla (Kuntze, 1920). A lectotype of the latter is designated. Eloeophila albofascia (Alexander, 1975) is established as a new junior synonym of E. apicata (Loew, 1871). Descriptions are provided of E. bipartita sp. n. (North Italy), E. delmastroi sp. n. (North Italy), E. lucasi sp. n. (South Italy and Sicily), E. maroccana sp. n. (Morocco, Spain), E. martinovskyi sp. n. (South Italy), E. minor sp. n. (Czech Republic, Slovakia), E. pectinistylus sp. n. (Spain), E. punctulata sp. n. [Cyprus, Greece (Crete)], E. sparsipunctum sp. n. (Bulgaria), and E. tigricosta sp. n. (Spain). A key to males of all West Palaearctic species is presented.
\end{abstract}

\section{INTRODUCTION}

Eloeophila Rondani, 1856 is a moderately large and widely distributed genus of the subfamily Limnophilinae, comprising 77 species-group taxa found throughout the Palaearctic, Nearctic, Afrotropical and Oriental regions (Oosterbroek, 2008). It has been less investigated because of its considerable infraspecific variability in wing pattern and uniformity in the structure of the male terminalia. Eleven Eloeophila species were known from the West Palaearctic. The taxonomy and distribution of most of them are well documented in the literature. Eloeophila albofascia (Alexander, 1975), from Iran, the only nonEuropean species of the eleven, is established here as a new junior synonym of E. apicata (Loew, 1871). Three species, E. czernyi (Strobl in Czerny \& Strobl, 1909), E. laciniata (Edwards, 1928), and E. pusilla (Kuntze, 1920), which are little-known and have restricted ranges, are redescribed, and a lectotype of the latter is designated. In addition, ten new species are described, mostly from the south west Palaearctic. Some new characters are used to distinguish the species. Only male terminalia are considered and illustrated for all the species described. Females are associated with males based on external characters. A key to males of all West Palaearctic species is presented.

The morphological terminology adopted here essentially follows McAlpine (1981), except that for the wing veins, which is that of Hennig (1954) (Fig. 29). Some special terms used in this paper are referred to in Fig. 2 and/or explained in the text. Unless otherwise stated, colours are described from dry-mounted specimens. Male terminalia were prepared by boiling in a solution of $10 \%$ $\mathrm{KOH}$ and preserved in glycerine in a sealed plastic tube pinned with the appropriate specimen. Line drawings were made using a drawing tube (camera lucida) attached to a compound microscope. Measurements were made using an ocular grid of the straight-line distance between the attachment of a wing and its tip and the longest per- pendicular distance between the anterior and posterior margins of a wing. Photographs were taken with a digital camera attached to a stereoscopic microscope.

The following acronyms of museums and collections are used in the text: BMNH - The Natural History Museum [formerly British Museum (Natural History)], London, UK; JKL - Collection of J. Kramer, Leicester, England, UK; JSO - Collection of J. Starý, Olomouc, Czech Republic; MZLS - Musée cantonal de zoologie, Lausanne, Switzerland; NHMW - Naturhistorisches Museum, Vienna, Austria; NMBA - Naturhistorisches Museum des Benediktinerstifts, Admont, Austria; SMOC - Slezské zemské muzeum, Opava, Czech Republic; SMTD - Staatliche Naturhistorische Sammlungen, Museum für Tierkunde, Dresden, Germany; USNM - National Museum of Natural History, Smithsonian Institution, Washington, D.C., USA; ZFMK - Zoologisches Forschungsmuseum Alexander Koenig, Bonn, Germany; ZMAN - Zoölogisch Museum, Universiteit van Amsterdam, Amsterdam, The Netherlands.

\section{TAXONOMY AND MORPHOLOGY OF WEST PALAEARCTIC ELOEOPHILA}

Externally, Eloeophila is characterized by the presence of a supernumerary cross-vein in cell $\mathrm{M}$ (called here the supernumerary $\mathrm{m}-\mathrm{cu}$ ) as well as an abundantly spotted wing pattern (Edwards, 1938; Dienske, 1987). There is a group of macrotrichia on the wing membrane in the distal tip of cell $\mathrm{R}_{4}$, which is difficult to see and not recorded previously; sometimes macrotrichia are also present in neighbouring cells. This may be another diagnostic character for Eloeophila because in other Limnophilinae the wing membrane is without macrotrichia or the distribution of macrotrichia is different (e.g., Adelphomyia Bergroth, 1891, Paradelphomyia Alexander, 1936, Pilaria Sintenis, 1889). The male terminalia of Eloeophila are 
distinguished by a flattened, darkly pigmented outer gonostylus (Edwards, 1938; Dienske, 1987).

The colour of the body of West Palaearctic Eloeophila is various hues of brown (mostly dark brown) suffused with grey pruinosity. The antennae are short in both sexes, not as long as the head and thorax combined (longer in E. trimaculata, especially the males), with the scape and pedicel dark brown. The flagellum differs in the various species, ranging from obscure yellow to brown. The pattern on the prescutum and scutum (here only the area from the anterior edge of the prescutum to the transverse suture is considered) is brown, without grey pruinosity, and somewhat shiny, varying among the species, generally consisting of two median and two lateral stripes, the latter much shorter than the former, both occasionally variously reduced and supplemented with other markings. This pattern, however, is indistinct in specimens preserved in ethanol. The pleuron is not quite shiny, usually with two longitudinal stripes.

General appearance of the wing pattern is sometimes diagnostic for a species or a group of species, but does vary. The pattern consists of seven larger spots on the anterior margin of the wing (the anterior or costal spots), viz. (1) over the humeral cross-vein, (2) at middle of $R$, (3) over the origin of Rs, (4) at the tip of $\mathrm{Sc}_{1},(5)$ over $\mathrm{R}_{2}$ (so-called cross-vein $\mathrm{r}$ ) and the tip of $\mathrm{R}_{1}$ (pterostigma), (6) at the tip of $\mathrm{R}_{3}$, and (7) at the tip of $\mathrm{R}_{4}$ (cf. Edwards, 1938). In addition, all vertical veins are seamed, and circular clouds are present at the tips of all longitudinal veins, except $R_{5}$. Another circular spot or cloud may be present before the tip of $\mathrm{A}_{2}$ and a streak is sometimes discernible along $R_{5}$. This basic pattern (Figs 30, 32, 35), which is not fully developed in E. trimaculata, may be supplemented with additional spots or dots (referred to here as additional markings), more or less numerous and variously fused, along the longitudinal veins (Figs 29, 31, $33,34)$. The wing outline also differs according to species, with the width-length ratio ranging from about $1: 3$ to $1: 4$. The posterior margin of wings of males that have broad wings is angled shortly before the tip of $A_{2}$ (Fig. 32 ), whereas the posterior margin of narrow wings is not angled and is evenly curved, being broadest shortly beyond the tip of $\mathrm{A}_{2}$ (Figs 29-31, 33-35). The wing venation is rather uniform within the genus, yet variable in detail even within a species. Some species differ in the position of the supernumerary $\mathrm{m}-\mathrm{cu}$ in respect to the extent of Rs or the tip of $\mathrm{A}_{2}$ and the comparative length of fork $\mathrm{M}_{1}-\mathrm{M}_{2}$ and its petiole $\left(\mathrm{M}_{1+2}\right)$, but these differences may have little taxonomic value.

The legs may differ in that their setae may be conspicuously long and protruding, especially on the femora and tibiae (E. czernyi), or comparatively short and more or less decumbent (e.g., E. punctulata sp. n.), but there are various intermediate states. The femora are either predominantly obscure yellow with abruptly darkened tips, slightly differing in the extent of the apical darkening in individual species, or more or less gradually darkened towards tip, without a sharp colour change, or, exception- ally, entirely yellow, without any darkening (E. minor sp. n.).

As usual, the structure of the male terminalia is essential for distinguishing the species, yet identification may be difficult due to the uniformity of some structures and variability of others. Tergite 9 differs slightly in outline, but its shape may vary according to the aspect viewed. There is a lip-like projection in the middle of the posterior margin of sternite 9 , of little taxonomic value for most of the species, but more pronounced in E. maculata (cf. Edwards, 1938: 82, Text Fig. 15a) than in the others. The gonocoxite is generally cylindrical, more or less enlarged proximally, with a group of variously pronounced teeth on the inner base, and more conspicuously produced ventro-distally in E. laciniata (Fig. 5). The flattened outer gonostylus, sometimes species-specific in shape, may, however, be subject to variation. It has a more or less distinct crest along the proximal half of its outer margin. (The crest is mostly bent dorsally in West Palaearctic species, thus not very visible in dorsal aspect.) The outer gonostylus is serrate along the outer margin of the distal half, ending in a terminal spine. This spine may vary in size relative to the width of the subapical emargination on its inner margin. The emargination ends proximally in a more or less pronounced, mostly rounded subapical angle or subacute tooth. The shape of the inner gonostylus also shows some differences, but is less useful because of the fleshy nature of this structure.

The naming of the various structures lateral to the aedeagus in Limoniidae raises problems. This paper does not solve homology and terminology problems. The paddle-like appendages in Eloeophila are here called parameres (Fig. 2, pm) because they seem to be homologous with the so named structures in Symplecta Meigen, 1830 (cf. Starý \& Brodo, 2009), although the apparently homologous structures in Dicranophragma Osten Sacken, 1860 are termed interbases (cf. Starý \& Reusch, 2009). The parameres may bear setulae on their apical portions, discernible at higher magnifications, but this trait may differ even within a species. There is a more or less sclerotized plate below the aedeagus (called here the lower shelf) extending distally to produce a membranous lateral projection on each side of the aedeagus and a median one just below it or fused to its lateral margins. (The lateral projections of the lower shelf are occasionally greatly developed and conspicuously shaped in the Limnophilinae, such as in Phylidorea Bigot, 1854 and Idioptera Macquart, 1834, and may well be considered the "second order parameres".) Thus, the aedeagal complex in Eloeophila, sometimes rather small and difficult to study, is made up of the following parts (Fig. 2 and other respective figures): The paramere $(\mathrm{pm})$, the lower shelf (lsh) with the lateral (lplsh) and median (mplsh) projections, the lateral apodeme (lap), the aedeagus (aed), the vesica or sperm pump (vs), and the apodeme of the vesica (apvs). Any or all of these parts may differ according to species. There are considerable differences in the length of the aedeagus (less so in its thickness). Further useful features may be found in the relative position of the tips 
of the lateral projections of the lower shelf to the median projection and in the shape of the vesica and its apodeme. Those species with a very short aedeagus (not reaching the tips of the parameres) generally have a rather uniform aedeagal complex. There is variation among the species in the size of the male terminalia relative to the size of the entire insect.

\section{KEY TO MALES OF WEST PALAEARCTIC SPECIES OF ELOEOPHILA}

1 Antenna longer than head and thorax combined; wing pattern reduced, no clouds at tips of longitudinal veins. Europe; for wing and male terminalia see Edwards, 1938, Pl. 4, Fig. 17 and Text Fig. 15g. .... E. trimaculata (Zetterstedt, 1838)

- Antenna shorter than head and thorax combined; wing with at least basic pattern (as described above)........... 2

2 Wing with markings on longitudinal veins in addition to basic pattern (Figs 29, 31, 33, 34). . . . . . . . . . . 3

- Wing with only basic pattern (Figs 30, 32, 35). ...... 11

3 Wing broad in middle (about $1: 3$ ), with posterior margin angled before tip of $\mathrm{A}_{2}$. Male terminalia with aedeagus very short, not exceeding tip of paramere........... 4

- Wing narrow (about $1: 3.5$ to $1: 4$ ), with posterior margin evenly curved (Figs 29, 31, 33, 34). Male terminalia with aedeagus long, exceeding tip of paramere (Figs 4, 10, 12,

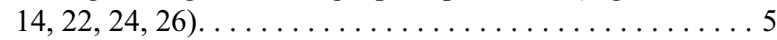

4 Comparatively large species (wing length 7.8-9.8 mm); wing with numerous additional markings on longitudinal veins. Male terminalia with conspicuous median lip-like projection on posterior margin of sternite 9. West Palaearctic, ranging to Kazakhstan; for wing and male terminalia see Edwards, 1938, Pl. 4, Figs 11-14, and Text Figs 15a, c. .... E. maculata (Meigen, 1804) Medium-sized species (wing length 5.9-8.2 mm); wing with additional markings on longitudinal veins few or sometimes even absent. Male terminalia with lip-like projection on sternite 9 much less pronounced. West Palaearctic; for wing and male terminalia see Edwards, 1938, Pl. 4, Figs 1-7, and Text Fig. 15b. ......... E. submarmorata (Verrall, 1887)

5 Wing very narrow (about $1: 4$ ); supernumerary m-cu beyond tip of $\mathrm{A}_{2}$ (Fig. 29); setae on legs conspicuously long and projecting, about twice as long as diameter of femur. Male terminalia: Figs 3, 4. France (Corsica), Italy (Sardinia and Sicily), Spain.

E. czernyi (Strobl in Czerny \& Strobl, 1909)

- Wing broad (about 1 : 3.5); supernumerary m-cu at or before tip of $\mathrm{A}_{2}$ (Figs 31, 33, 34); setae on legs not especially long or projecting. ............... 6

6 Male terminalia with aedeagus distinctly bifid (Figs 9, 10). North Italy............... E. bipartita sp. n.

- Male terminalia with aedeagus simple (Figs 12, 14, 22, 24, 26) . . . . . . . . . . . . . . . . . . . . . 7

7 Wing with fork $\mathrm{M}_{1}-\mathrm{M}_{2}$ more than twice as long as its petiole (Fig. 31). Male terminalia with median projection on lower shelf extended considerably posteriorly as dark pigmented flange along aedeagus (Figs 11, 12). North Italy. . .

E. delmastroi sp. n. Wing with fork $\mathrm{M}_{1}-\mathrm{M}_{2}$ mostly shorter, from twice as long to subequal in length to its petiole (Figs 33, 34). Male terminalia with median projection on lower shelf not especially conspicuous (Figs 14, 22, 24, 26). . . . . . . . . . 8

8 Wing pattern abundant and extensive, with numerous additional markings on longitudinal veins, including those between anterior spots (Fig. 33). Male terminalia: Figs 23, 24. Cyprus, Greece (Crete).......... E. punctulata sp. n.
Wing pattern less abundant and less extensive, with few additional markings on longitudinal veins sometimes present between anterior spots (Fig. 34) . . . . . . . . . . . 9

9 Male terminalia: outer gonostylus with rather high and conspicuous crest; aedeagus very long, exceeding tip of paramere by nearly half its length (Figs 21,22 ). Spain........

E. pectinistylus sp. n.

- Male terminalia: outer gonostylus with low and less obvious crest; aedeagus shorter, only slightly exceeding tip of paramere (Figs 13, 14, 25, 26). . . . . . . . . . . 10

10 Male terminalia: aedeagus rather stout; vesica broad, spherical (Figs 25, 26). Bulgaria ... E. sparsipunctum sp. n. Male terminalia: aedeagus comparatively slender; vesica narrow, ovoid (Figs 13, 14). South Italy and Sicily........ E. lucasi sp. n.

11 Wing broad in middle (about $1: 3$ ), with posterior margin angled before tip of $\mathrm{A}_{2}$ (Fig. 32) . . . . . . . . . 12 Wing narrow (about $1: 3.5$ to $1: 4$ ), with posterior margin evenly curved (Figs 30,35$) \ldots \ldots \ldots \ldots \ldots$. . . . . . . 14

12 Comparatively large species (wing length 7.7-10.1 mm); antenna with brown flagellum; wing with comparatively large anterior spots. Europe; for wing and male terminalia see Edwards, 1938, P1. 4, Fig. 10, and Text Fig. 15d. . . . . . E. mundata (Loew, 1871) Smaller species (wing length less than $7.5 \mathrm{~mm}$ ); antenna with yellow flagellum, slightly darkened distally; wing with reduced anterior spots. . . . . . . . . . . . . 13

13 Body colouration pale greyish brown; wing membrane tinged yellowish; femora yellow, slightly and narrowly darkened at tips. Male terminalia: outer gonostylus with terminal spine comparatively large and subapical angle prominent; aedeagus long, exceeding tip of paramere by nearly half its length. Europe except for north; for wing and male terminalia see Savchenko, 1986, Figs 155/2, 161/2. . . Body colouration dark greyish brown; wing membrane hyaline; femora yellow throughout. Male terminalia: outer gonostylus with terminal spine small and subapical angle not especially prominent; aedeagus very short, not reaching tip of paramere (Figs 19, 20). Czech Republic, Slovakia. . . .

E. minor sp. n.

14 Wing pattern rather extensive and largely fused, arranged in three more or less apparent transverse bands with wide continuous blank hyaline band in middle of wing. Male terminalia: Figs 1, 2. West Palaearctic, ranging to Turkmenistan; for wing see Edwards, 1938, Pl. 4, Fig. 9............ ....................... E. apicata (Loew, 1871)

Wing pattern not as above............... 15

15 Very small species, wing length $4.0-4.5 \mathrm{~mm}$ (Fig. 30). Male terminalia with aedeagus very short, not reaching tip of paramere (Figs 7, 8). France (Corsica).

E. pusilla (Kuntze, 1920)

- Larger species, wing length more than $5.3 \mathrm{~mm}$. Male terminalia with aedeagus exceeding tip of paramere (Figs 6, 16,

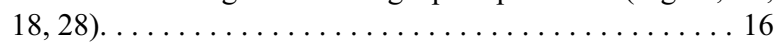

16 Wing moderately broad, about 1 : 3.5. Male terminalia: gonocoxite produced ventro-distally in flap-like expansion; outer gonostylus with subacute subapical tooth on inner margin (Figs 5, 6). France (Corsica), Italy (Sardinia). . . . . . ................... E. laciniata (Edwards, 1928) Wing narrow, about $1: 4$ (Fig. 35). Male terminalia: gonocoxite not especially produced ventro-distally; gonostylus with at most rounded subapical angle on inner margin (Figs $15,17,27) \ldots \ldots \ldots \ldots \ldots \ldots \ldots \ldots \ldots \ldots \ldots$ 
17 Wing with anterior spots larger than their interspaces (Fig 35). Male terminalia: Figs 27, 28. Spain. . . . . . . . . . E. tigricosta sp. n.

- Wing with anterior spots smaller than their interspaces. . 18

18 Comparatively small species, wing length $5.3-6.2 \mathrm{~mm}$. Male terminalia: outer gonostylus with terminal spine small and inner margin rounded, without subapical angle; aedeagus moderately long, only slightly exceeding tip of paramere (Figs 15, 16). Morocco, Spain. . . . . . . . . . . . . Larger species, wing length more than $6.5 \mathrm{~mm}$. Male terminalia: outer gonostylus with large terminal spine and inner margin with subapical angle obvious; aedeagus very long, exceeding tip of paramere by nearly half its length (Figs 17, 18). . . . . . . . . . . . . . . . . . . . . 19

19 Male terminalia: crest on outer margin of outer gonostylus ending in sharp tooth; aedeagus extremely slender; apodeme of vesica narrow, spike-shaped. Europe; for wing and male terminalia see Edwards, 1938, P1. 4, Fig. 8, and Text Figs $15 \mathrm{e}, \mathrm{h} \ldots \ldots \ldots \ldots \ldots$. . . . . verralli (Bergroth, 1912)

- Male terminalia: crest on outer margin of outer gonostylus indistinct, without tooth; aedeagus not especially slender; apodeme of vesica broad, fan-shaped (Figs 17, 18). South Italy. . . . . . . . . . . . . . . . . . E. martinovskyi sp. n.

\section{NEW SYNONYMY}

\section{Eloeophila apicata (Loew, 1871)}

(Figs 1, 2)

Ephelia apicata Loew, 1871: 9 (description).

Limnophila (Elaeophila) apicata: Edwards, 1938: 79 (redescription, synonymy with maculatifrons), Text Figs 15f, i (male terminalia), Pl. 4, Fig. 9 (wing).

Eloeophila apicata: Savchenko et al., 1992: 217 (Palaearctic catalogue, synonymy with maculatifrons, fixation of maculatifrons as the correct original spelling over masculatifrons).

Eloeophila apicata: Starý, 2007: 24 (lectotype designation of maculatifrons).

Ephelia maculatifrons Pierre, 1924: 89 (description), Figs 45 (wing), 46 (male terminalia), 47 (female terminalia), 48 (head).

Limnophila (Elaeophila) albofascia Alexander, 1975: 134 (description), Fig. 8 (male terminalia) - syn. n.

Examination of the holotype slide of $L$. (E.) albofascia, especially the male terminalia, revealed that this species is identical with E. apicata. Hence, the former is established here as a new junior synonym of the latter. The conception of E. apicata used here accords with that of other authorities (e.g., de Meijere, 1921, Pl. 4, Figs 95a, b; Edwards, 1938, Text Figs 15f, i, Pl. 4, Fig. 9; Savchenko, 1986, Figs 155/1, 161/1), and its male terminalia are illustrated (Figs 1, 2).

Type material examined. Limnophila (Elaeophila) albofascia: Holotype $\hat{o}$ (original designation): Iran, Durbadam, 3.vii.1956, slide, (F. Schmid leg.) (USNM), labelled: "Limnophila / (Elaeophila) / albofascia Al. / 0 / Durbadam / July 3, 1956 / (Fernand Schmid) / The Alexander Collection / of CraneFlies / 81 / HOLOTYPE 13236" (hand-written except for the printed collection name). The slide (Canada balsam) has a wing under one circular coverslip and terminalia under another.

Distribution. Europe, Georgia, Iran, Turkmenistan.

\section{DESCRIPTIONS}

\section{Eloeophila czernyi (Strobl in Czerny \& Strobl, 1909)}

(Figs 3, 4, 29)

Ephelia Czernyi Strobl in Czerny \& Strobl, 1909: 140 (description).

Eloeophila czernyi: Savchenko et al., 1992: 218 (Palaearctic catalogue).

Diagnosis. Medium-sized species within Eloeophila. Wing narrow, with basic pattern supplemented with additional markings. Legs with femora obscure yellow, darkened at tips and setae long and projecting. Male terminalia with outer gonostylus with small terminal spine, aedeagus moderate in length and thickness and apodeme of vesica finger-shaped. Wing length 6.5-8.7 $\mathrm{mm}$.

Redescription. Male. Head. Antenna with flagellum predominantly brown, first flagellomere sometimes yellowish.

Thorax. Prescutum and scutum with pattern barely distinct, both median and lateral stripes suffused with greyish pruinosity; two additional, more pronounced, elongate marks between median and lateral stripes, one placed anteriorly, the other posteriorly, coinciding with row of setae. Wing (Fig. 29) narrow (about $1: 4$ ), with posterior margin evenly arched. Fork $\mathrm{M}_{1}-\mathrm{M}_{2}$ mostly slightly longer than its petiole, but considerably variable in length. Supernumerary m-cu opposite about one-third length of Rs and beyond tip of $\mathrm{A}_{2}$. Wing with pattern rather extensive, intensely dark brown, anterior spots often larger than their interspaces; additional markings on longitudinal veins, including a few between anterior spots. Legs with femora obscure yellow, comparatively broadly and intensively darkened at tips. Setae on legs conspicuously long and projecting, about twice diameter of femur.

Abdomen. Male terminalia (Figs 3, 4): Gonocoxite rather long and comparatively slender, enlarged at base and only slightly produced ventro-distally. Outer gonostylus with crest on outer margin distinct in certain views; terminal spine small; inner margin with subapical angle rounded and moderately pronounced. Paramere without or with setulae. Tip of lateral projection of lower shelf level with sclerotized posterior edge of median projection, but membranous extension discernible reaching more distally along aedeagus. Aedeagus moderate in length and thickness, distinctly exceeding tip of paramere. Vesica short-ovoid, with apodeme moderately long, finger-shaped.

Female resembling male in general appearance.

Material examined (22 $\hat{\sigma}, 8 \uparrow)$. France: Corsica: $5 \mathrm{~km} \mathrm{E} \mathrm{Col}$ de Vergio (1,250 m), 18.vi.1981, 10; 4 km E Zonza (760 m), 13.vi.1981, 1ठ; S Lac de Barrage de l'Ospedale $(920 \mathrm{~m})$, 12.vi.1981, 50; SW Calacuccia, direction Col de Vergio (1,050 m), 17.vi.1981, 9ठิ, 5 (all H. Malicky leg.) (all ZFMK; in ethanol) [listed by Podenas et al. (1997)]; $10 \mathrm{~km}$ SW Calacuccia $(1,000$ m), 17.vi.1981, 10ิ, 1 우 (H. Malicky leg.) (JSO; dried from ethanol); Vizzavona (1,000-1,100 m), 7.-8.viii.1971, $1 \hat{\delta}^{\text {, }}$ (850-950 m), 12.-24.viii.1971 10 (A.C. \& W.N. Ellis leg.) (JSO). Italy: Sardinia: Fiume Tirso, $10 \mathrm{~km}$ SE Budduso (810 m), 

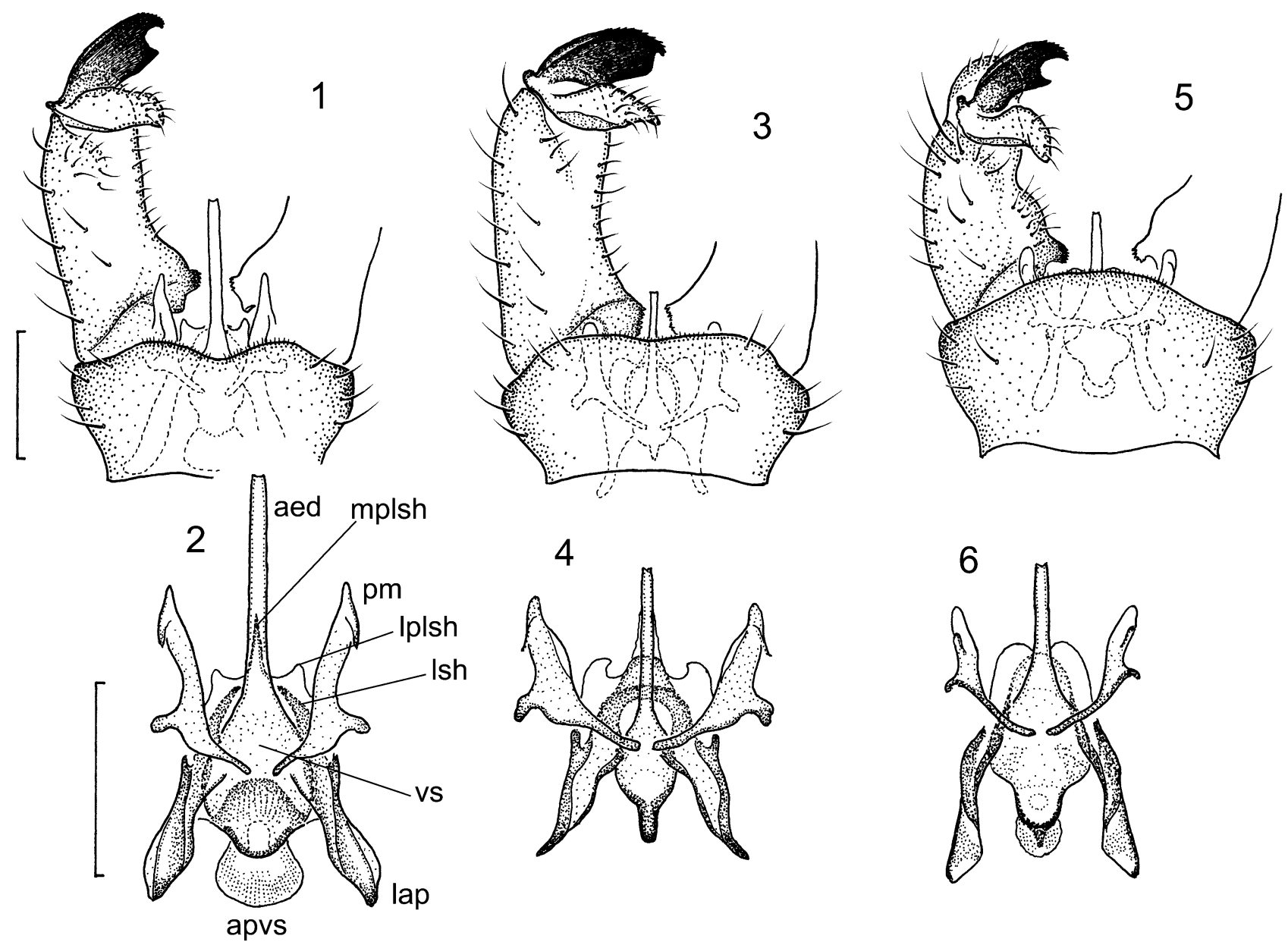

Figs 1-6: Male terminalia. 1-2 - Eloeophila apicata (Slovakia: Polana Mts), general view, dorsal (1) and aedeagal complex, dorsal (2); 3-4 - E. czernyi (Spain: Andalucia), general view, dorsal (3) and aedeagal complex, dorsal (4); 5-6 - E. laciniata (France: Corsica), general view, dorsal (5) and aedeagal complex, dorsal (6). Scale bars $0.25 \mathrm{~mm}$. aed - aedeagus; apvs - apodeme of vesica; lap - lateral apodeme; lplsh - lateral projection of lower shelf; lsh - lower shelf; mplsh - median projection of lower shelf; pm - paramere; vs - vesica (sperm pump).

30.v.1981, 1 \%; N S. Lussurgiu (700 m), 4.vi.1981, 1 \%; below Satzu [Setzu] (240 m), 9.vi.1981, 1 đo (all H. Malicky leg.) (all ZFMK; in ethanol). Sicily: Monti Madoni, $3.5 \mathrm{~km}$ N Pollizzi Gen., small rivers in orchard terraces (mainly chestnut) along old watermills $(500 \mathrm{~m}), 21 .-23 . x .1993,10$ đ (P. Oosterbroek \& C. Hartveld leg.) (JSO). Spain: Andalucia: Málaga env., Sierra Palmitera nr. Puerto dei Madroño, 8.iv.2005, 1 đ (J. Starý leg.) (JSO).

Distribution. France (Corsica), Spain. First records for Italy (Sardinia and Sicily).

Discussion. Eloeophila czernyi was described by Strobl (in Czerny \& Strobl, 1909) probably from a single male collected in Spain (Algeciras). Although most of Strobl's types of Limoniidae and Pediciidae are deposited in NMBA, and some re-examinations published (Starý, 1994, 2006), the type of E. czernyi is not among them. It was also not traced in NHMW. The name czernyi is applied here to the species identified as such by Mendl from Corsica (Podenas et al., 1997). Recently this species was also collected in Spain (see Material examined). It fits very well the original description of E. czernyi in general appearance of the wing pattern (numerous additional markings on longitudinal veins) and colouration of the antennae (predominantly brown). Strobl's statement
(Czerny \& Strobl, 1909: 141) that the wings are "kaum halb so breit als bei marmorata [= maculata]" (hardly half as wide as in maculata) is to be understood as an estimate rather than a measurement. In fact, the wings in what is here considered to be E. czernyi are not so much narrower than in E. maculata, yet they are the narrowest of all the species with additional markings on longitudinal veins. The species is also distinctive in having very long and projecting setae on its legs. The male terminalia of $E$. czernyi somewhat resemble those of E. lucasi sp. n., differing in details of the aedeagal complex, such as the lower shelf (less sclerotized in E. lucasi sp. n.), the aedeagus (parallel-sided in E. czernyi, slightly tapered towards apex in E. lucasi sp. n.), and the apodeme of the vesica (shorter, finger-shaped in E. czernyi, longer, spikeshaped in E. lucasi sp. n.) (cf. Figs 4 and 14).

\section{Eloeophila laciniata (Edwards, 1928)}

(Figs 5, 6)

Idioptera (Ephelia) laciniata Edwards, 1928: 185 (description), Fig. $5 b$ (male terminalia).

Eloeophila laciniata: Savchenko et al., 1992: 218 (Palaearctic catalogue). 
Diagnosis. Medium-sized species within Eloeophila. Wing moderately broad, with only basic pattern. Legs with femora obscure yellow, darkened at tips. Male terminalia with gonocoxite produced ventro-distally in conspicuous flap-like expansion, outer gonostylus with both terminal spine and subapical tooth large, aedeagus moderate in length and thickness and apodeme of vesica broad and rounded. Wing length $6.2-6.5 \mathrm{~mm}$.

Redescription. Male. Head. Antenna with flagellum obscure yellow, slightly darkened distally.

Thorax. Prescutum and scutum with pattern barely distinct (discoloured in ethanol), with additional spot lateral to lateral stripes. Wing moderately broad (about $1: 3.5$ ), with posterior margin evenly curved. Fork $\mathrm{M}_{1}-\mathrm{M}_{2}$ subequal in length to or longer than its petiole. Supernumerary m-cu opposite about one-fourth length of Rs and shortly before tip of $\mathrm{A}_{2}$. Wing with only basic pattern, dark brown and moderately extensive; anterior spots smaller than or subequal to their interspaces. Legs with femora obscure yellow, darkened at tips, darkening not especially broad. Setae on legs comparatively short, decumbent, subequal in length to diameter of femur.

Abdomen. Male terminalia (Figs 5, 6): Gonocoxite comparatively short and stout, considerably enlarged at base and conspicuously produced ventro-distally in flaplike expansion. Outer gonostylus with indistinct crest on outer margin; terminal spine large; wide subapical emargination on inner margin ending proximally in sharp subapical tooth. Paramere without setulae. Tip of lateral projection of lower shelf slightly exceeding posterior edge of median projection. Aedeagus moderate in length and thickness, distinctly exceeding tip of paramere. Vesica rather broad, generally spherical, with apodeme broad and rounded.

Female resembling male in general appearance.

Type material examined. Holotype $\delta$ (monotypy): France, Corsica, Calvi, 10.-25.iv.1928 (F.W. Edwards leg.) (BMNH), labelled "Calvi, / N. coast" (printed), "Corsica. / 10.-25.iv.1928. / F.W. Edwards / B.M. 1928-214" (printed), "Idioptera / (Ephelia) / laciniata Edw. / F.W. Edwards. / det. VI.1928." (partly printed), "Type" (a red-margined circular label), "HOLOTYPE" (a red-margined circular label), "HOLOTYPE / Idioptera / laciniata / Edwards / det. J.E. Chainey, 1995" (partly printed). The specimen is glued onto a celluloid point; all legs attached, left wing somewhat crumpled, apex of abdomen cut off. Terminalia in Canada balsam on a square celluloid slide, pinned with the specimen.

Other material examined $(2 \widehat{\delta}, 1 \uparrow)$. France: Corsica: Porto S. Evisa (in valley) $(600 \mathrm{~m}), 18 . v i .1981,10^{\top}$ (H. Malicky leg.) (ZFMK, in ethanol) [listed by Podenas et al. (1997)]. Italy: Sardinia: Rio S. Girolamo (550 m), 27.v.1981, 1 đ; Rio Aratu, $3 \mathrm{~km}$ $\mathrm{S}$ of the dam $(670 \mathrm{~m}), 6 .-7 . v i .1981,1$ ( ) (all H. Malicky leg.) (all ZFMK, in ethanol); River Calaresu, $12 \mathrm{~km} \mathrm{NW} \mathrm{Villanova}$ Strisaili, along road SS389, 23.v.2000, 10 (J. Kramer leg.) (JKL).

Distribution. France (Corsica). First records for Italy (Sardinia).

Discussion. In general appearance, including the wing pattern, E. laciniata resembles E. mundata, except that the former has narrower wings, with posterior margin evenly curved. The structure of the male terminalia is unique within West Palaearctic Eloeophila in that the gonocoxite has a conspicuous flap-like expansion ventrodistally (Fig. 5). The outer gonostylus has a prominent subacute tooth on inner margin proximal to a wide subapical emargination. In E. apicata and E. verralli, a similar tooth may be present, but it is not as sharp and prominent as in E. laciniata.

\section{Eloeophila pusilla (Kuntze, 1920)}

(Figs 7, 8, 30)

Ephelia pusilla Kuntze, 1920: 56 (description).

Eloeophila pusilla: Savchenko et al., 1992: 219 (Palaearctic catalogue).

Diagnosis. Very small species within Eloeophila. Wing moderately broad, with only basic pattern. Legs with femora yellow, darkened at tips. Male terminalia with outer gonostylus with terminal spine small, aedeagus very short and apodeme of vesica very small. Wing length 4-4.5 mm.

Redescription. Male. Head. Antenna with flagellum yellow, slightly darkened distally.

Thorax. Prescutum and scutum with pattern barely distinct, with only median stripes apparent. Wing (Fig. 30) moderately broad (1:3.2), with posterior margin evenly curved. Fork $\mathrm{M}_{1}-\mathrm{M}_{2}$ shorter than its petiole. Supernumerary m-cu opposite about one-fifth length of Rs and before tip of $\mathrm{A}_{2}$. Wing with only basic pattern, brown and spots reduced in extent, anterior spots smaller than their interspaces. Legs with femora yellow, narrowly darkened at tips. Setae on legs rather long (longer than in E. minor sp. n., but not projecting nor as long as in E. czernyi).

Abdomen. Male terminalia (Figs 7, 8): Gonocoxite short, moderately enlarged at base and only slightly produced ventro-distally. Outer gonostylus with indistinct crest on outer margin; terminal spine small; inner margin with pronounced, rectangular subapical angle. Paramere without or with a few setulae. Tip of lateral projection of lower shelf distinctly exceeding posterior edge of median projection. Aedeagus very short, slightly exceeding tip of lateral projection of lower shelf and level with tip of paramere. Vesica ovoid, with apodeme very small.

Female unknown.

Type material examined. The species was described from five males ["Ich besitze 50 , welche Herr W. Schnuse 1899 bei Vizzavona (Korsika) gefangen hat." (Kuntze 1920: 56)]. I examined all the syntypes; the best preserved is designated a lectotype. Lectotype $\hat{\delta}$ (present designation): France, Corsica, Vizzavona, Monte d'Oro, vii.1899 (W. Schnuse leg.) (SMTD), labelled "Corse / Monte d'Oro / VII.1899" (printed, date handwritten), "Samml. A. Kuntze / Vermächtn. 1933. I" (printed), "Eloeophila / pusilla Kuntze / det. H. Mendl 85 / Typus" (handwritten, "Typus" in red ink), "TYPUS" (printed, red). Labelled as lectotype ("LECTOTYPE / Ephelia / pusilla Kuntze $\widehat{\delta} / \mathrm{J}$. Starý 2006"; printed red label). The specimen is micro-pinned on a stage, in fair condition, with only left mid and hind legs and right hind leg missing; apex of abdomen cut off. Terminalia dissected by the present author and placed in a sealed plastic tube with glycerine, pinned with the specimen. Paralectotypes: 40 mounted and with the same locality labels as lectotype, labelled as "paratypes" by H. Mendl and provided with red "paratype" labels attached probably by the museum staff, based 


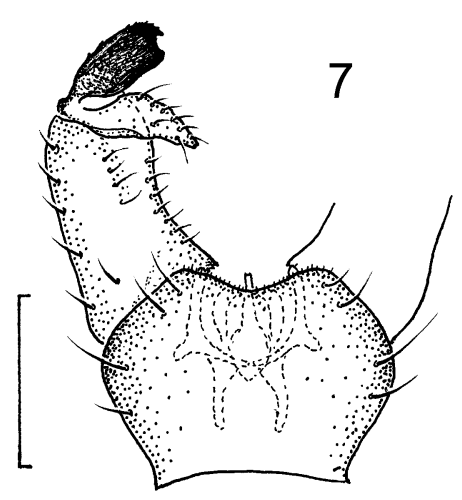

8

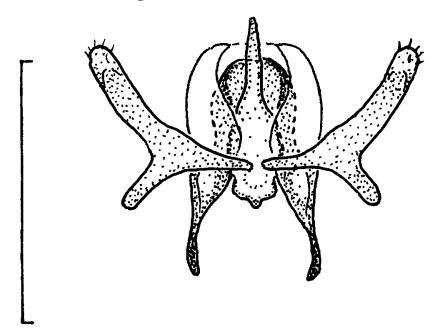

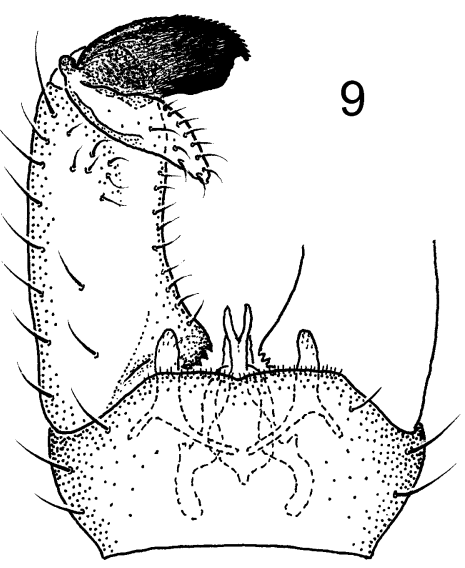

10

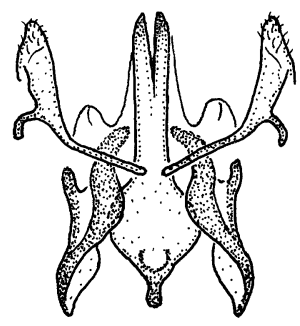

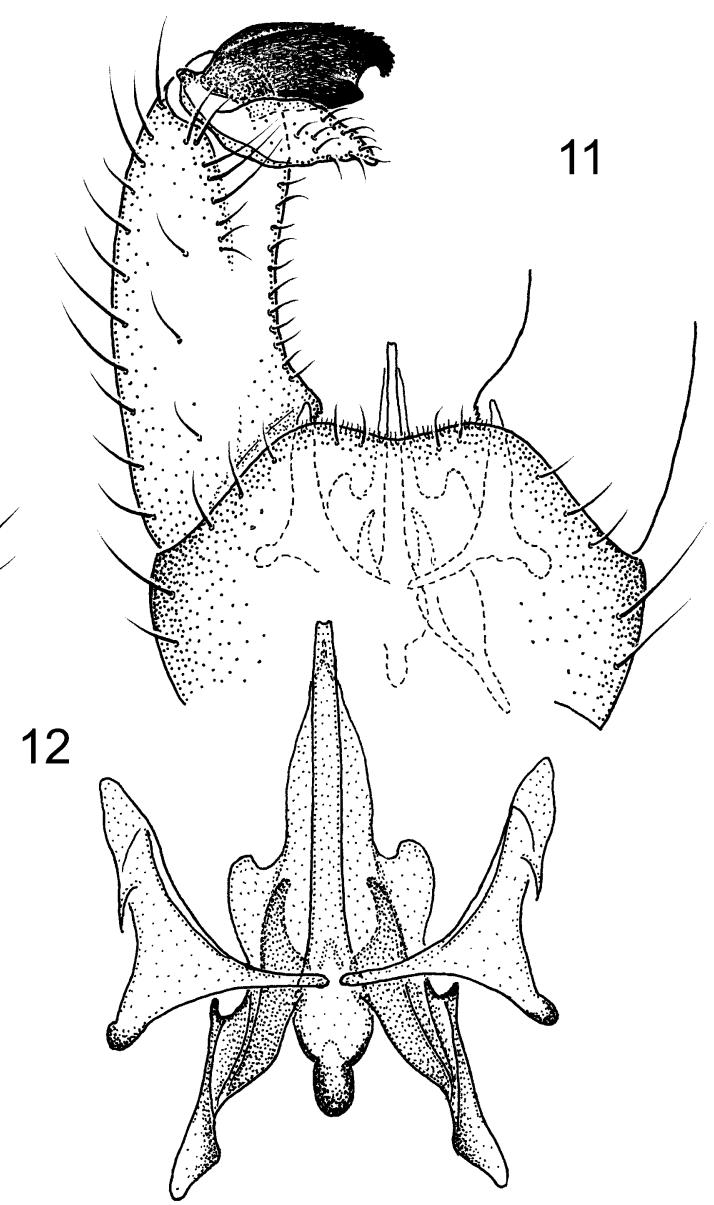

Figs 7-12: Male terminalia. 7-8 - Eloeophila pusilla (paralectotype), general view, dorsal (7) and aedeagal complex, dorsal (8); 9-10-E. bipartita sp. n. (holotype), general view, dorsal (9) and aedeagal complex, dorsal (10); 11-12 - E. delmastroi sp. n. (holotype), general view, dorsal (11) and aedeagal complex, dorsal (6). Scale bars $0.25 \mathrm{~mm}$.

on Mendl's nomination. Accordingly labelled as paralectotypes by the present author. The specimens are mostly without legs, two are without wings (some legs and wings placed, probably by $\mathrm{H}$. Mendl, in a corked glass tube, pinned separately); two specimens dissected, one by $\mathrm{H}$. Mendl, one by the present author, with the terminalia now in glycerine in sealed plastic tubes, pinned with the specimens. The lectotype is designated here to stabilize the concept of the name for the species redescribed and illustrated in this paper, in case the undissected specimens belong to a different species.

Distribution. France (Corsica).

Discussion. This species is known only from the type series, being distinctively very small. It differs from the next smallest and probably closely related species, $E$. minor sp. $\mathrm{n}$., in having relatively narrower wings, with posterior margin evenly curved (posterior margin of the male wing is angled in E. minor sp. n.) (cf. Figs 30 and 32) and the femora narrowly darkened at tips (entirely yellow in E. minor sp. n.). The male terminalia are generally similar in both species, with the aedeagus very short, level with the tips of the parameres. The aedeagus is tapered towards apex in E. pusilla (more or less parallelsided in E. minor sp. n.) and the lateral apodemes are almost parallel to each other (diverging from each other in E. minor sp. n.) (cf. Figs 7, 8 and 19, 20).

\section{Eloeophila bipartita sp. $\mathbf{n}$.}

(Figs 9, 10)

Diagnosis. Medium-sized species within Eloeophila. Wing moderately broad, with basic pattern supplemented with additional markings. Legs with femora obscure yellow, barely darkened at tips. Male terminalia with outer gonostylus with terminal spine small, aedeagus distinctly bifid, moderate in length and apodeme of vesica fingershaped. Wing length $6.2-7.3 \mathrm{~mm}$.

Description. Male. Head. Antenna with flagellum obscure yellow, slightly darkened distally.

Thorax. Prescutum and scutum with pattern barely distinct (possibly discoloured), consisting of long, entire median stripes and irregular lateral mark composed of a few spots. Wing moderately broad (about $1: 3.5$ ), with posterior margin evenly curved. Fork $\mathrm{M}_{1}-\mathrm{M}_{2}$ absent on both wings in holotype. Supernumerary $\mathrm{m}$-cu only slightly beyond origin of Rs and slightly before tip of $\mathrm{A}_{2}$. Wing with pattern moderate in extent, brown, somewhat diffuse, anterior spots smaller than their interspaces; additional markings on longitudinal veins sometimes occurring between anterior spots. Legs with femora obscure yellow, with apical darkening barely distinct. Setae on legs moderate in length, decumbent, slightly longer than diameter of femur. 
Abdomen. Male terminalia (Figs 9, 10): Gonocoxite rather long and slender, moderately enlarged at base and only slightly produced ventro-distally. Outer gonostylus with crest on outer margin distinct in certain views; terminal spine small; inner margin broadly rounded, subapical angle not pronounced. Paramere with setulae. Tip of lateral projection of lower shelf exceeding posterior edge of paired sclerotized pincer-like structure of lower shelf, but membranous median projection of shelf discernible reaching more distally along aedeagus. Aedeagus distinctly bifid, stout, moderate in length, slightly exceeding tip of paramere. Vesica spherical, with apodeme short, finger-shaped.

Female resembling male in general appearance (see Discussion below for $\mathrm{M}_{1}-\mathrm{M}_{2}$ fork).

Type material. Holotype $\delta$ : Italy, Piemonte, Mondovi (CN), Govoni, C. na Sciolla (350 m), 3.v.2001, 1ठ, (G.B. Delmastro leg.) (SMOC). Paratype: $1 \%$, same data as for holotype (JSO).

Etymology. The new species is named bipartita (= bipartite) because of its bifid aedeagus. An adjective in nominative singular.

Distribution. Italy (north).

Discussion. The two specimens available, both somewhat teneral, were dried from ethanol. Fork $\mathrm{M}_{1}-\mathrm{M}_{2}$ is lacking on both wings in the male holotype, but is present in the female paratype (collected syntopically and synchronously) being about twice as long as its petiole. $E$. bipartita sp. n. is remarkable in having a distinctly bifid aedeagus (Figs 9, 10). Yet this feature is not entirely peculiar to West Palaearctic Eloeophila, being found, much less pronounced and only visible at higher magnifications, in E. maculata (cf. Reusch, 1988: 198, Fig. 15c). This feature may help to differentiate aberrant specimens of E. maculata from, e.g., E. submarmorata.

\section{Eloeophila delmastroi sp. $\mathbf{n}$.}

(Figs 11, 12, 31)

Diagnosis. Comparatively large species within Eloeophila. Wing moderately broad, with basic pattern supplemented with additional markings. Legs with femora obscure yellow, darkened at tips. Male terminalia with outer gonostylus with terminal spine moderately large, aedeagus very long and apodeme of vesica rather broad, rounded. Wing length 7.1-8.5 mm.

Description. Male. Head. Antenna with flagellum entirely brown.

Thorax. Prescutum and scutum with pattern barely distinct (possibly discoloured), consisting of long, entire median stripes and irregular lateral marks of a few more or less fused spots; several dots between median and lateral stripes posteriorly, coinciding with row of setae. Wing (Fig. 31) moderately broad (about 1 : 3.5), with posterior margin evenly curved. Fork $\mathrm{M}_{1}-\mathrm{M}_{2}$ more than twice as long as its petiole. Supernumerary m-cu opposite about one-fourth length of Rs and shortly before tip of $A_{2}$. Wing with pattern extensive, dark brown, anterior spots somewhat smaller than their interspaces; additional markings on longitudinal veins, including a few between anterior spots. Legs with femora obscure yellow, broadly darkened at tips. Setae on legs comparatively short, decumbent, subequal in length to diameter of femur.

Abdomen. Male terminalia (Figs 11, 12): Gonocoxite rather long and slender, enlarged at base and only slightly produced ventro-distally. Outer gonostylus with crest on outer margin distinct in certain views; terminal spine moderate in size; inner margin with moderately wide subapical emargination ending proximally in comparatively prominent subapical angle. Paramere without setulae. Tip of lateral projection of lower shelf exceeding or level with posterior edge of paired sclerotized pincer-like structure of lower shelf, but median projection of lower shelf considerably extended posteriorly as comparatively broad, somewhat darkly pigmented flange along aedeagus. Aedeagus very long, moderate in thickness, exceeding tip of paramere by nearly half its length. Vesica ovoid, with apodeme rather broad, rounded.

Female unknown.

Type material. Holotype $\widehat{\delta}$ : Italy, Piemonte, Villafranca Piemonte (TO), Cappella di Missione (260 m), 10.viii.1999 (G.B. Delmastro leg.) (SMOC). Paratypes (7ठ) : Italy: Piemonte: Vigone (TO), S. Maria, Bealera dei Bastioni (261 m), 2.v.2001, 20, 19.iii.2002, 20, 30.ix.2005, 1ठ; Villafranca Piemonte (TO), Cappella di Missione (260 m), 10.viii.1999, 1 ô (all G.B. Delmastro leg.); Saluzzo (CN), Cascinasse, loc. Fosso Risagna (270 m), 23.ix.2005, $1 \delta^{\star}$ (G.B. Delmastro \& M. Evangelista leg.) (all JSO).

Etymology. The new species is named in honour of its collector, Dr. Giovanni B. Delmastro (Museo Civico di Storia Naturale, Carmagnola, Italy), in thanks for highly interesting material of Limoniidae, Pediciidae and other families. A noun in genitive singular.

Distribution. Italy (north).

Discussion. All the specimens were dried from ethanol therefore the pattern on the prescutum and scutum may be somewhat discoloured. E. delmastroi sp. n. has wings with fork $\mathrm{M}_{1}-\mathrm{M}_{2}$ more than twice as long as its petiole (Fig. 31), differing thus from all the species, except perhaps E. bipartita sp. n., an entirely different species. In the structure of the male terminalia, E. delmastroi sp. n. likewise is highly distinctive, especially in that the median projection of the lower shelf is greatly developed, forming a darkly pigmented flange along the aedeagus that might be mistaken for the aedeagus itself (Fig. 12).

Veins are uniformly dark in Fig. 31 showing the wing of $E$. delmastroi sp. n. whereas they are paler on sections not covered with the wing pattern in other species (Figs $29,30,32-35)$. The former is probably an artifact caused by photographing the wing of E. delmastroi sp. n. from a specimen dried from ethanol.

\section{Eloeophila lucasi sp. n.}

(Figs 13, 14)

Diagnosis. Comparatively large species within Eloeophila. Wing moderately broad, with basic pattern supplemented with additional markings. Legs with femora obscure yellow, darkened at tips. Male terminalia with outer gonostylus with terminal spine small, aedeagus moderate in length and thickness and apodeme of vesica spike-shaped. Wing length 7.4-9.4 mm. 

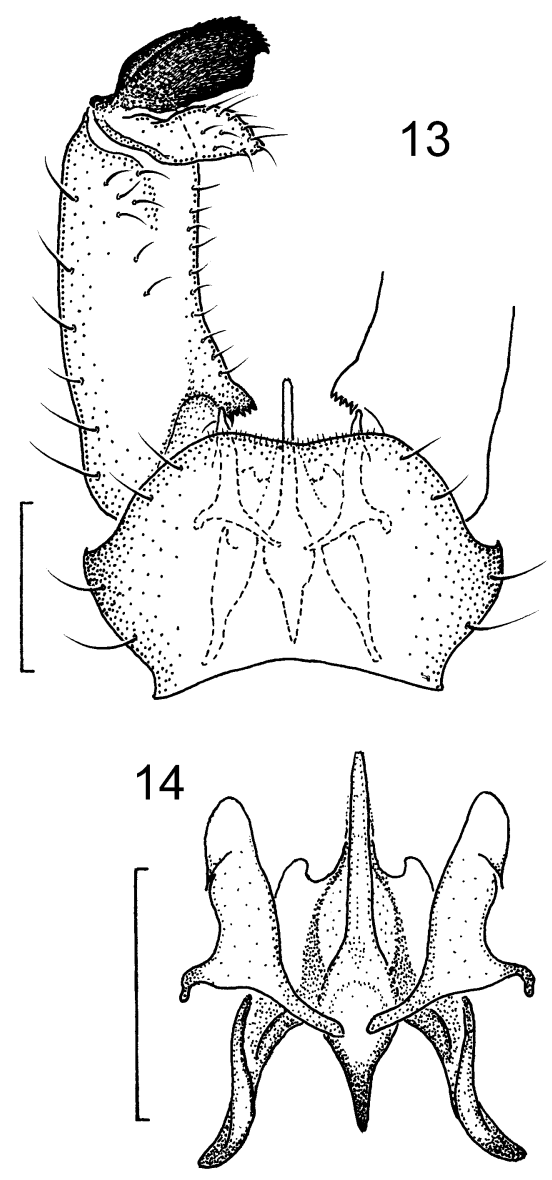
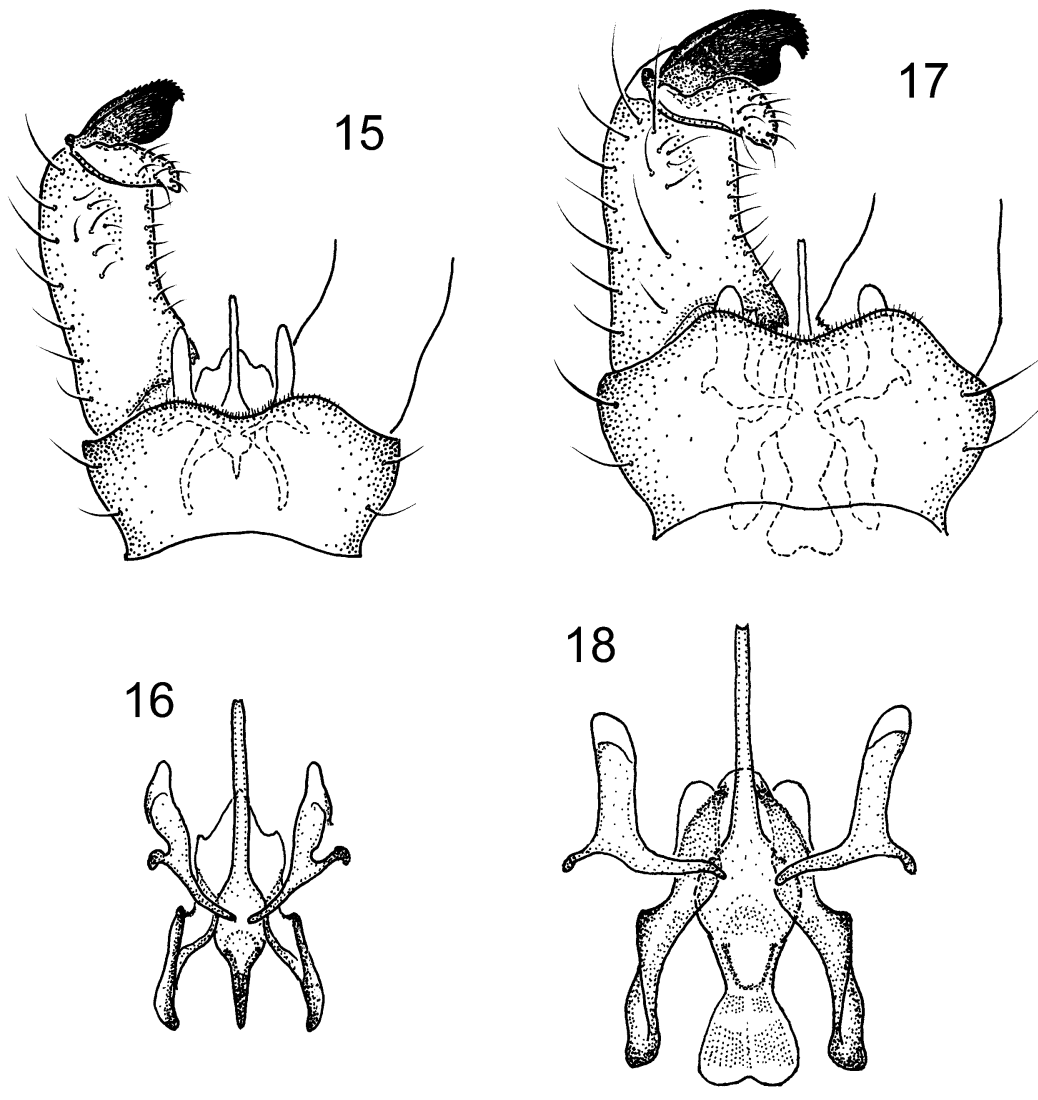

Figs 13-18: Male terminalia. 13-14 - Eloeophila lucasi sp. n. (paratype, Italy: Sicily), general view, dorsal (13) and aedeagal complex, dorsal (14); 15-16-E. maroccana sp. n. (holotype), general view, dorsal (15) and aedeagal complex, dorsal (16); 17-18 E. martinovskyi sp. n. (paratype), general view, dorsal (17) and aedeagal complex, dorsal (18). Scale bars $0.25 \mathrm{~mm}$.

Description. Male. Head. Antenna with flagellum obscure yellow, slightly darkened distally, first flagellomere brighter yellow.

Thorax. Prescutum and scutum with pattern distinct, median stripes gradually fading out posteriorly; lateral stripes reduced; stripe between median and lateral stripes clearly distinct, ranging from prescutal pit to transverse suture and coinciding with row of setae; oblong spot along paratergite, mostly fused to lateral stripe. Wing moderately broad (about $1: 3.5$ ), with posterior margin evenly curved. Fork $\mathrm{M}_{1}-\mathrm{M}_{2}$ slightly longer than or subequal in length to its petiole. Supernumerary m-cu opposite about one-fourth length of Rs and well before tip of $\mathrm{A}_{2}$. Wing with pattern moderate in extent of spots, dark brown, anterior spots mostly subequal in size to their interspaces, except for wide interspace between spots 3 and 4; additional markings on longitudinal veins, but mostly none between anterior spots. Legs with femora obscure yellow, moderately darkened at tips, darkening not especially broad (cf. E. czernyi). Setae on legs moderate in length, decumbent, slightly longer than diameter of femur.

Abdomen. Male terminalia (Figs 13, 14): Gonocoxite rather long and slender, moderately enlarged at base and only slightly produced ventro-distally. Outer gonostylus with crest on outer margin distinct in certain views; ter- minal spine small; inner margin with subapical angle rounded and moderately pronounced. Paramere without setulae. Tip of lateral projection of lower shelf not reaching partly sclerotized posterior edge of median projection, but membranous extension discernible and reaching more distally along aedeagus. Aedeagus moderate in length and thickness, slightly exceeding tip of paramere. Vesica ovoid, with apodeme spike-shaped, rather long.

Female resembling male in general appearance.

Type material. Holotype ơ: Italy, Sicily, Biviere di Cesaro (1,200-1,300 m), 30.vii.1961 (V.S. v.d. Goot, J.A.W. Lucas, Br. Theowald, G. Veberne leg.) (ZMAN). Paratypes (27 $\hat{o}, 6 \uparrow, 2$ specimens): Italy: Abruzzo: Celano (AQ), Fucino, strada 16 sorgente, 29.v.1993, 1 o (B.G. Osella leg.) (JSO; in ethanol). Calabria: Sila Grande (CS), Calmigliatello (1,300 m), 21.vii.1959, 1\%; Sila Grande (CS), San Pietro in Guarano $(650 \mathrm{~m})$,

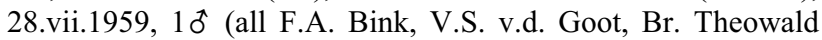
leg.) (all ZMAN). Sicily: Biviere di Cesaro $(1,200-1,300 \mathrm{~m})$,

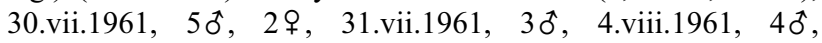
6.viii.1961, 13ठ, 3 ㅇ, 2 specimens (V.S. v.d. Goot, J.A.W. Lucas, Br. Theowald, G. Veberne leg.) (ZMAN, JSO).

Etymology. This new species is named in honour of one of its collectors, Jan A.W. Lucas (Rotterdam, The Netherlands), a well-known Dutch entomologist and keen collector of Diptera, especially Syrphidae. A noun in genitive singular.

Distribution. Italy (south, including Sicily). 
Discussion. There is a group of generally similar species that resemble E. maculata in having additional markings on longitudinal veins, but differ from it in having somewhat narrower wings (about $1: 3.5$ ). E. lucasi sp. n. is most similar to E. sparsipunctum sp. n., differing from it in the structure of the male terminalia, namely a comparatively slender aedeagus and rather narrow, ovoid vesica (in E. sparsipunctum sp. n., the aedeagus is rather stout and the vesica broad, spherical) (cf. Figs 14 and 26).

\section{Eloeophila maroccana sp. $\mathbf{n}$.}

(Figs 15, 16)

Diagnosis. Small species within Eloeophila. Wing narrow, with only basic pattern. Legs with femora gradually darkened towards tips. Male terminalia with outer gonostylus with terminal spine small, aedeagus long and slender and apodeme of vesica spike-shaped. Wing length $5.3-6.2 \mathrm{~mm}$

Description. Male. Head. Antenna with flagellum entirely brown.

Thorax. Pattern on prescutum and scutum barely distinct (discoloured), only median stripes discernible. Wing narrow (slightly more than $1: 4$ ), with posterior margin evenly curved. Fork $M_{1}-M_{2}$ subequal in length to its petiole. Supernumerary $\mathrm{m}$-cu about opposite from one-fifth to one-third length of Rs and opposite tip of $\mathrm{A}_{2}$. Wing with only basic pattern, rather geyish brown and spots restricted in extent, anterior spots smaller than their interspaces. Legs with femora gradually darkened towards tips. Setae on legs moderate in length, decumbent, slightly longer than diameter of femur.

Abdomen. Male terminalia (Figs 15, 16): Gonocoxite slender, cylindrical, not enlarged at base, only slightly produced ventro-distally. Outer gonostylus with crest on outer margin distinct in certain views; terminal spine small, inner margin broadly rounded, subapical angle weakly pronounced. Paramere without setulae. Median projection of lower shelf distinctly exceeding lateral projection. Aedeagus slender and long, distinctly exceeding tip of paramere. Vesica ovoid, with apodeme long, spikeshaped.

Female unknown.

Type material. Holotype $\delta$ : Morocco, Ht Atlas, Massif Toubkal, Okaïmeden (2,500-2,800 m), 2.-8.vii.1977, 1 ơ (H. \& T. v. Oorschot, E. Houkes \& P. Oosterbroek leg.) (ZMAN). Paratype (1 $\left.\sigma^{\star}\right)$ : Spain: Andalucia: Algeciras, 12.-20.v.1925, 10 (H. Zerny leg.) (NHMW) (listed as dalei by Lackschewitz, 1940).

Etymology. The name of this new species, maroccana, is derived from the name of the country where the holotype comes from. The name is deemed to be a latinized adjective in nominative singular.

Distribution. Morocco, Spain.

Discussion. The holotype is damaged, with the thorax discoloured by grease, the wings with numerous tears and only the left hind femur and tibia attached. The paratype is well preserved, but the thorax is deformed by a pin, therefore, the pattern on the thorax, likewise, is not very discernible. E. maroccana sp. n. belongs to a group of species around $E$. verralli, distinguished by generally very dark colouration, including the antennae, wing pattern and legs, as well as narrow wings (about $1: 4$ ) without any additional markings. Previously only $E$. verralli was known to exhibit these characters. Now, in addition to E. maroccana sp. n., E. martinovskyi sp. n. and E. tigricosta sp. n. are also included in this group. Within this group, E. maroccana sp. n. is distinct in the structure of the male terminalia, namely the shape of the outer gonostylus, which has a small terminal spine and broadly rounded inner margin with a weakly pronounced subapical angle (Fig. 15) (the other species all have a larger terminal spine, with comparatively wide subapical emargination, ending proximally in a distinct subapical angle, even tooth in E. verralli; for E. martinovskyi sp. n. and $E$. tigricosta sp. n., see Figs 17, 18 and 27, 28, respectively).

Since new species closely related to $E$. verralli are described here, previous records of E. verralli from Southern Europe should be confirmed. The record of $E$. verralli from Algeria by Savchenko (1986) is probably based on a misinterpretation of the record by Lackschewitz (1940, as dalei) from Algeciras (Spain), which in fact pertains to this species (see the paratype).

\section{Eloeophila martinovskyi sp. $\mathrm{n}$.}

(Figs 17, 18)

Diagnosis. Medium-sized species within Eloeophila. Wing narrow, with only basic pattern. Legs with femora gradually darkened towards tips. Male terminalia with outer gonostylus with terminal spine comparatively large, aedeagus very long and apodeme of vesica broad, fanshaped. Wing length $6.9-8.1 \mathrm{~mm}$.

Description. Male. Head. Antenna with flagellum entirely brown.

Thorax. Prescutum and scutum with pattern distinct, median stripes long, lateral stripes reduced to circular spot; another spot lateral to lateral stripe, close to paratergite. Wing narrow (about $1: 4$ ), with posterior margin evenly curved. Fork $\mathrm{M}_{1}-\mathrm{M}_{2}$ slightly shorter than or subequal in length to its petiole. Supernumerary $\mathrm{m}$-cu opposite about one-fourth length of Rs and shortly before tip of $\mathrm{A}_{2}$. Wing with only basic pattern, rather greyish brown to even blackish, and moderate in extent, anterior spots smaller than or subequal to their interspaces. Legs with femora gradually darkened towards tips. Setae on legs comparatively short, decumbent, subequal in length to diameter of femur.

Abdomen. Male terminalia (Figs 17, 18): Gonocoxite not especially long, rather stout, enlarged at base, only slightly produced ventro-distally. Outer gonostylus with crest on outer margin distinct in certain views; terminal spine comparatively large; wide subapical emargination on inner margin ending proximally in conspicuous rounded subapical angle. Paramere without setulae. Tip of lateral projection of lower shelf level with posterior edge of median projection. Aedeagus slender and very long, exceeding tip of paramere by nearly half its length. Vesica ovoid, with apodeme large, broad distally, fanshaped, sometimes with median excision on posterior margin.

Female unknown. 

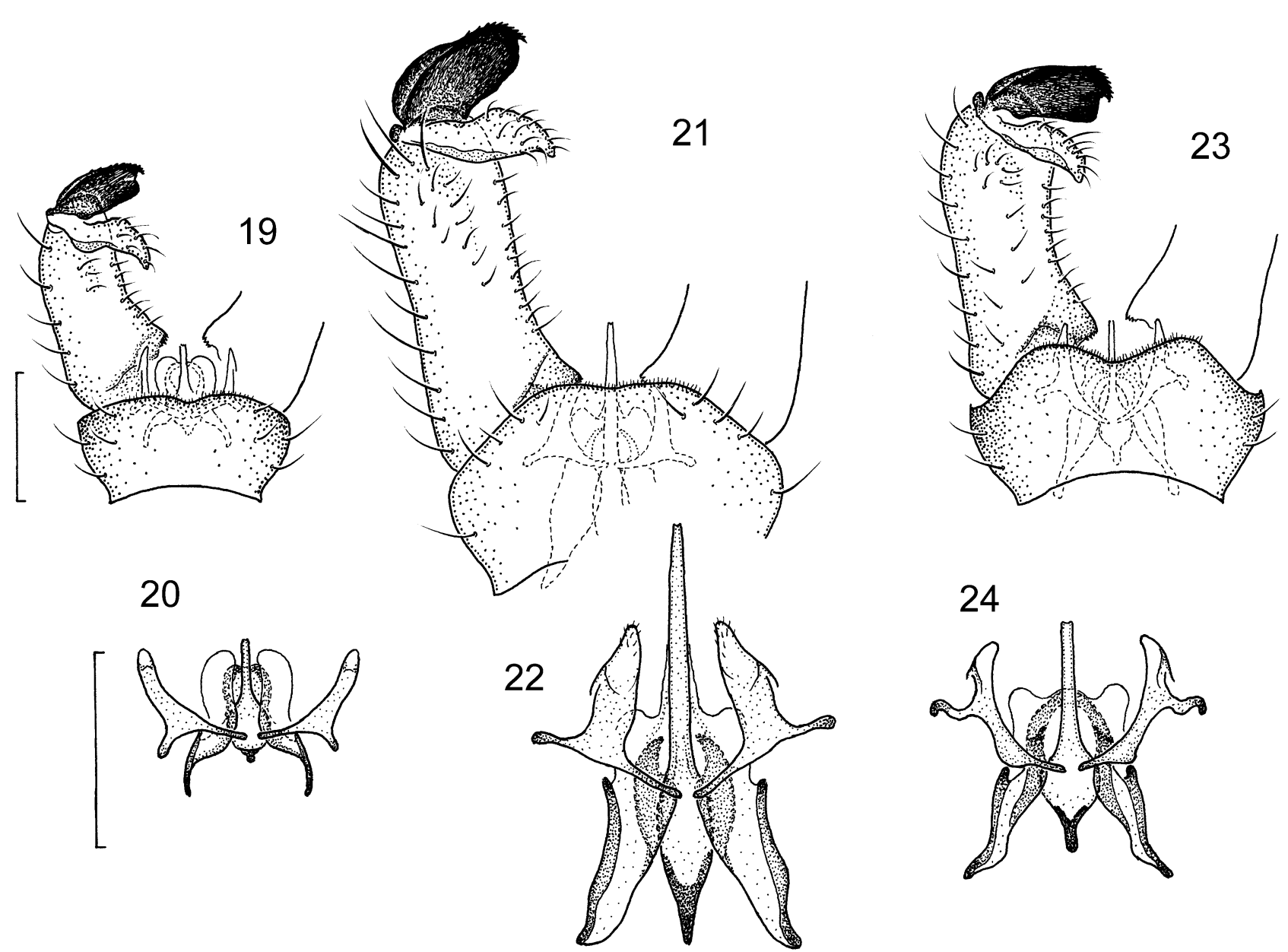

Figs 19-24: Male terminalia. 19-20 - Eloeophila minor sp. n. (paratype, Czech Republic: Moravia), general view, dorsal (19) and aedeagal complex, dorsal (20); 21-22 - E. pectinistylus sp. n. (paratype, Spain: Region Madrid), general view, dorsal (21) and aedeagal complex, dorsal (22); 23-24-E. punctulata sp. n. (holotype), general view, dorsal (23) and aedeagal complex, dorsal (24). Scale bars $0.25 \mathrm{~mm}$.

Type material. Holotype $\widehat{\widehat{t}}$ : Italy, Calabria, Santa Maria del Cedro (CS), Lao valley, 31.v.1996 (J. Martinovský leg.) (SMOC). Paratypes $(8 \AA)$ : Italy: Calabria: Santa Maria del Cedro (CS), Lao valley, 31.v.1996, 60ิ, 1.vi.1996, 10; Marcelina (CS) env., Abatemarco shores, 3.vi.1996, 1 ô (all J. Martinovský leg.) (all JSO).

Etymology. This new species is named in honour of its collector, the late Dr. Jaroslav Martinovský (Olomouc, Czech Republic), a distinguished specialist on the Tipulidae and many other lower dipteran families. A noun in genitive singular.

Distribution. Italy (south).

Discussion. This species belongs to the group around $E$. verralli, as specified in the Discussion of E. maroccana sp. n. Within this group, E. martinovskyi sp. n. is distinguished especially by the structure of the male terminalia, namely the shape of the apodeme of the vesica, which is large, broad distally, fan-shaped, sometimes with a median excision on posterior margin (Fig. 18).

\section{Eloeophila minor sp. $\mathbf{n}$.}

(Figs 19, 20, 32)

Diagnosis. Small species within Eloeophila. Wing broad, with only basic pattern. Legs with femora entirely yellow. Male terminalia with outer gonostylus with ter- minal spine small and both aedeagus and apodeme of vesica very short. Wing length 5.3-7.2 $\mathrm{mm}$.

Description. Male. Head. Antenna with flagellum yellow, slightly darkened distally.

Thorax. Prescutum and scutum with pattern fairly distinct, median stripes distinct anteriorly, suffused with greyish pruinosity posteriorly, developing into laterally displaced line coinciding with row of setae; lateral stripes represented by oval spot; another spot apparent lateral to lateral stripe, occasionally both spots fused to each other. Wing (Fig. 32) broad (about $1: 3$ ), with posterior margin angled. Fork $\mathrm{M}_{1}-\mathrm{M}_{2}$ slightly shorter than its petiole. Supernumerary m-cu opposite about one-fourth length of Rs and well before tip of $\mathrm{A}_{2}$. Wing with only basic pattern, brown and considerably reduced in extent of spots; anterior spots much smaller than their interspaces. Legs with femora pale yellow, without any darkening. Setae on legs moderate in length, decumbent, slightly longer than diameter of femur.

Abdomen. Male terminalia (Figs 19, 20): Gonocoxite moderate in length and thickness, enlarged at base and only slightly produced ventro-distally. Outer gonostylus with crest on outer margin distinct in certain views; terminal spine small; inner margin with subapical angle 
rounded and moderately pronounced. Paramere with a few setulae. Tip of lateral projection of lower shelf distinctly exceeding posterior edge of median projection. Aedeagus very short, only slightly exceeding tip of lateral projection of lower shelf, not reaching tip of paramere. Vesica spherical, with apodeme very short.

Female resembling male in general appearance, except for evenly curved posterior margin of wing.

Type material. Holotype $\widehat{\delta}$ : Czech Republic, Moravia, Jívová nr. Olomouc, 19.vi.1980 (J. Starý leg.) (SMOC). Paratypes $(350 \hat{0}, 27$ ) : Czech Republic: Moravia: Bedřichov nr. Oskava, 15.vi.1970, 1ठ, 1우, 16.vi.1970, 1 đิ (J. Martinovský leg.); Jívová nr. Olomouc, 18.vi.1972, 10, 21.vi.1978, 1 \% ,

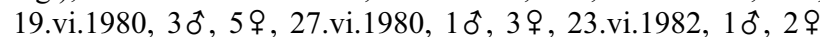
(J. Starý leg.); Hrubá Voda nr. Olomouc, 22.vi.1970, 10 (J. Starý leg.), 21.vi.1970, 20ิ, 8.vii.1972, 1 đ (J. Martinovský leg.); Nové Sady nr. Dolany, 14.vi.1970, 2 ô (J. Martinovský leg.); Moravskoslezské Bekydy Mts, Trojanovice, Bystrá valley, 15.vi.1989, 1 ㅇ (J. Starý leg.); Moravskoslezské Bekydy Mts, Košařiska, 17.vi.1999, 1 đo (J. Starý leg.; at light) (all JSO). Slovakia: Stakčín, Chotinka valley, 22.vi.1983, 60ิ, 1\%, 24.vi.1983, 3ठิ, 2ㅇ, 3.vi.1984, 10ิ, 6.vi.1985, 20ิ, 2우, 11.vi.1985, 3, 17.vi.1986, 20, 20.vi.1986, 1\%; Ruské, Cirocha shores, 7.vi.1985, 1 ठ; Ruský Potok, valley, 10.vi.1985, 1đ̄, 11.vii.1993, 2 đ̊; Nová Sedlica env., 13.vi.1986, 1 \%; Nová Sedlica, Zbojský brook, 21.vi.1991, 20 , 4 ㅇ (all J. Starý leg.) (all JSO).

Etymology. The name of this new species, minor (= smaller), refers to its small size. An adjective in nominative singular.

Distribution. Czech Republic, Slovakia.

Discussion. This species is readily distinguished by its small size and entirely yellow femora, without any apical darkening. The male terminalia have the aedeagal complex small, with aedeagus very short, thus resembling several other species, but based on the size and the wing pattern, E. minor sp. n. can only be confused with $E$. pusilla. The differences are specified in the Discussion of E. pusilla.

\section{Eloeophila pectinistylus sp. $\mathbf{n}$.}

(Figs 21, 22)

Diagnosis. Medium-sized species within Eloeophila. Wing moderately broad, with basic pattern supplemented with additional markings. Legs with femora yellow, darkened at tips. Male terminalia with outer gonostylus with terminal spine small, aedeagus very long and apodeme of vesica wedge-shaped. Wing length $6.7-7.1 \mathrm{~mm}$.

Description. Male. Head. Antenna with flagellum yellow, slightly darkened distally.

Thorax. Prescutum and scutum with pattern barely distinct, suffused with greyish pruinosity, but more visible in female paratypes, consisting of entire median stripes and comparatively long lateral stripes, with additional spots, including distinct line between median stripes. Wing moderately broad ( $1: 3.5)$, with posterior margin evenly curved. Fork $\mathrm{M}_{1}-\mathrm{M}_{2}$ longer than its petiole, occasionally twice so. Supernumerary $\mathrm{m}-\mathrm{cu}$ opposite from one-fifth to one-third length of Rs and from shortly before to level with tip of $A_{2}$. Wing with pattern brown, moderate in extent of spots, anterior spots generally subequal in size to their interspaces; additional markings on longitudinal veins including occasionally between anterior spots. Legs with femora yellow, narrowly darkened at tips. Setae on legs rather long and projecting, slightly shorter than twice diameter of femur.

Abdomen. Male terminalia (Figs 21, 22): Gonocoxite very long and slender, moderately enlarged at base and only slightly produced ventro-distally. Outer gonostylus with rather high crest on outer margin; terminal spine small; inner margin with subapical angle low, rounded, weakly pronounced. Paramere with setulae. Tip of lateral projection of lower shelf exceeding posterior edge of paired sclerotized pincer-like structure of lower shelf, but membranous median projection of shelf clearly reaching far more distally along aedeagus. Aedeagus very long, moderate in thickness, exceeding tip of paramere by nearly half its length. Vesica long-ovoid, with apodeme rather long, wedge-shaped.

Female resembling male in general appearance.

Type material. Holotype $\hat{\delta}$ : Spain, Region Madrid, Cercedilla, 8.vii.1950, 1 đ (F. Schmid leg.) (MZLS). Paratypes (1 $\delta^{\text {, }}$ 2 + ): Spain: Region Madrid: Cercedilla, 8.vii.1950, 10 (F. Schmid leg.) (JSO); Castilla y Leon: Avila, Sierra de Gredos, Arenas de San Pedro (550 m), 15.v.-4.vi.1976, 2 ㅇ (P. Oosterbroek \& E. Boersma leg.) (ZMAN).

Etymology. The name of this new species, pectinistylus (pecten $=$ comb, crest), refers to the comparatively high crest on the outer margin of the outer gonostylus. A noun in nominative singular, standing in apposition to the generic name.

Distribution. Spain.

Discussion. This species is distinguished by the comparatively high crest on the outer margin of the outer gonostylus (inferred from the two male specimens available). In addition, it has a very long aedeagus that exceeds beyond the tips of the parameres by nearly half its length, differing thus from species of similar general appearance (E. lucasi sp. n., E. punctulata sp. n., E. sparsipunctum sp. n.), in which the aedeagus is shorter (cf. Figs 21, 22 and 13, 14, 23, 24, 25, 26).

\section{Eloeophila punctulata sp. $\mathbf{n}$.}

(Figs 23, 24, 33)

Diagnosis. Medium-sized species within Eloeophila. Wing moderately broad, with basic pattern supplemented with numerous additional markings. Legs with femora obscure yellow, darkened at tips. Male terminalia with outer gonostylus with terminal spine small, aedeagus slender, moderate in length and apodeme of vesica fingershaped. Wing length $6.4-8.8 \mathrm{~mm}$.

Description. Male. Head. Antenna with flagellum obscure yellow, slightly darkened distally.

Thorax. Prescutum and scutum with pattern distinct, median stripes long and entire, lateral stripes short; additional spot anteriorly and row of dots posteriorly between median and lateral stripes, coinciding with row of setae; another spot lateral to lateral stripe. Wing (Fig. 33) moderately broad (about $1: 3.5$ ), with posterior margin evenly curved. Fork $\mathrm{M}_{1}-\mathrm{M}_{2}$ longer than to subequal in length to its petiole. Supernumerary $\mathrm{m}$-cu opposite about onefourth length of Rs and before tip of $\mathrm{A}_{2}$. Wing with pattern dark brown, abundant, extensive, with anterior spots 

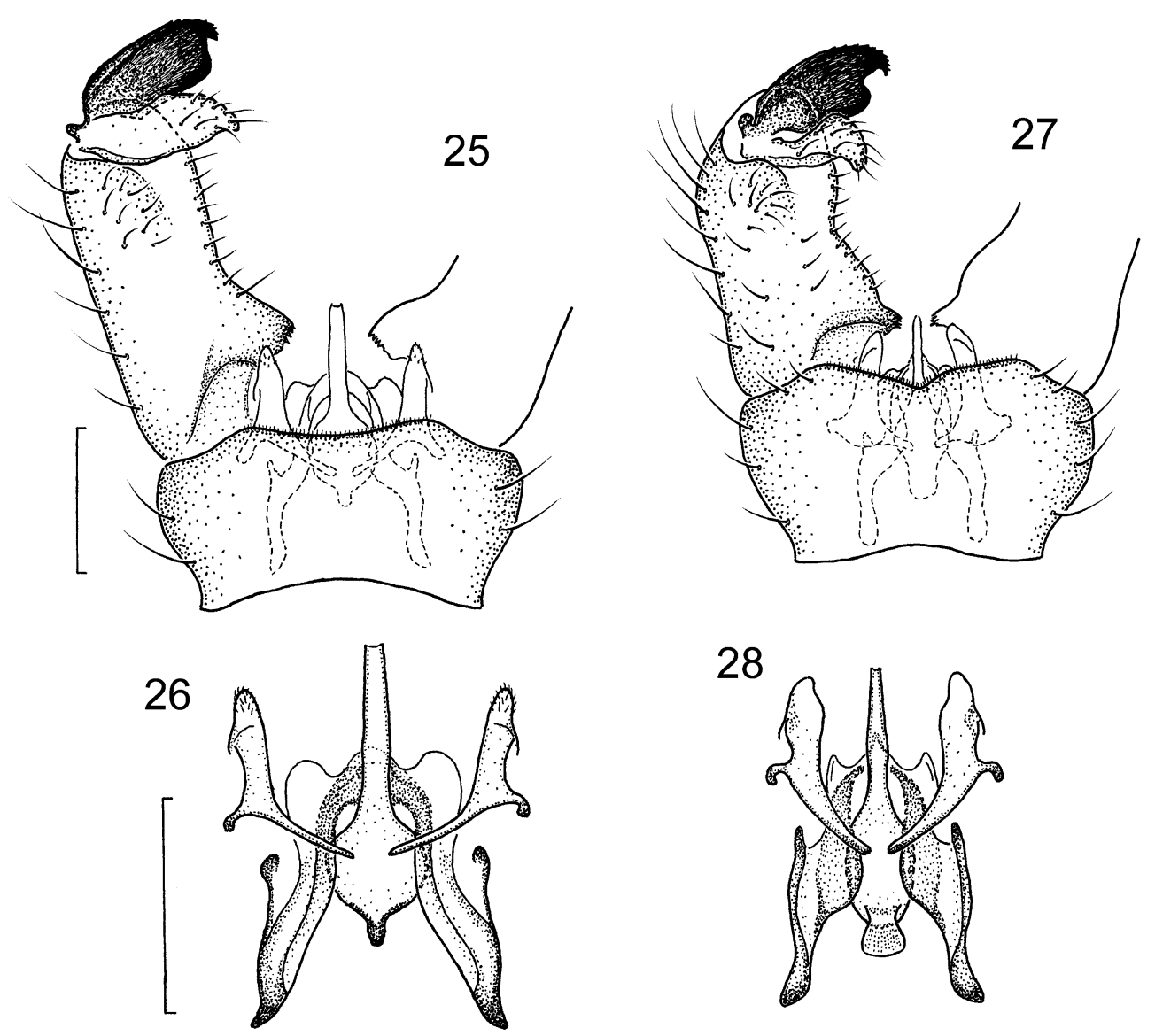

Figs 25-28: Male terminalia. 25-26 - Eloeophila sparsipunctum sp. n. (holotype), general view, dorsal (25) and aedeagal complex, dorsal (26); 27-28-E. tigricosta sp. n. (holotype), general view, dorsal (27) and aedeagal complex, dorsal (28). Scale bars $0.25 \mathrm{~mm}$.

mostly larger than their interspaces; basic pattern supplemented with numerous additional markings on longitudinal veins, including those between anterior spots. Legs with femora obscure yellow, darkened at tips, darkening not especially broad. Setae on legs comparatively short, decumbent, subequal in length to diameter of femur.

Abdomen. Male terminalia (Figs 23, 24): Gonocoxite rather long and slender, moderately enlarged at base and only slightly produced ventro-distally. Outer gonostylus with crest on outer margin distinct in certain views; terminal spine small; inner margin with subapical angle rectangular, distinct. Paramere without or with setulae. Tip of lateral projection of lower shelf level with posterior edge of median projection. Aedeagus slender, moderate in length, slightly exceeding tip of paramere. Vesica ovoid, with apodeme finger-shaped, moderate in length.

Female resembling male in general appearance.

Type material. Holotype $\widehat{\delta}:$ Greece, Crete, Khania Region, Kakopetros, brook, 23.v.2004 (J. Starý leg.) (SMOC). Paratypes (340ิ, 7 ㅇ, 1 specimen): Cyprus: Troodos Mts, river S of Mesopotamos Monastery $(900-1,100 \mathrm{~m}), 20 . x .1992,2 \hat{0}, 1 \%$; Troodos Mts, 0-3 km S of Agros (800-900 m), river valley, 26.x.1992, 19; Troodos Mts, river Kyros S of Pano Platres (900-1,100 m), 19.-24.x.1992, 1 ㅇ (all P. Oosterbroek \& F.M. Hartveld leg.); Troodos Mts, $2 \mathrm{~km} \mathrm{~N}$ of Pano Platres (1,200-1,250 m), 7.viii.1992, 10; Troodos Mts, Pano Platres (1,000 m), 3.viii.1992, 1 specimen (all H. de Jong leg.) (all
ZMAN). Greece: Crete: Khania Region: Kakopetros, brook, 23.v.2004, 13 oे, 2 \%; Voukolies, brook, 23.v.2004, $1 \delta^{\pi}$; Prases,

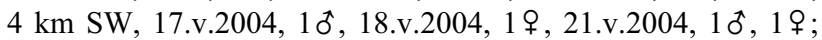
Prases, $2 \mathrm{~km} \mathrm{W,} \mathrm{21.v.2004,} \mathrm{9ð;} \mathrm{Nea} \mathrm{Roumata,} \mathrm{brook,}$ 21.v.2004, 1 đ; Alikianos, Xekollimenos River, 14.v.2004, 10, 17.v.2004, 1 के; Stilos, Kiliaris River, 13.v.2004, 2 क; Georgioupoli, marsh, 12.v.2004, 1 đ (all J. Starý leg.) (all JSO).

Etymology. The name of this new species, punctulata, is deemed to be a diminutive of punctata (= spotted) and refers to numerous additional spots and dots on the wing. The name is to be treated as a latinized adjective in nominative singular.

Distribution. Cyprus, Greece (Crete).

Discussion. The spots on the wing of this species are abundant, with numerous additional markings on longitudinal veins, including those between the anterior spots (Fig. 33). The aedeagal complex of the male terminalia most resembles that of E. czernyi and E. lucasi sp. n., differing especially in that a membranous extension on the median projection of the lower shelf is not apparent (cf. Figs 24 and 4, 14).

\section{Eloeophila sparsipunctum sp. n.}

(Figs 25, 26, 34)

Diagnosis. Comparatively large species within Eloeophila. Wing moderately broad, with basic pattern supplemented with additional markings. Legs with femora obscure yellow, darkened at tips. Male terminalia with 

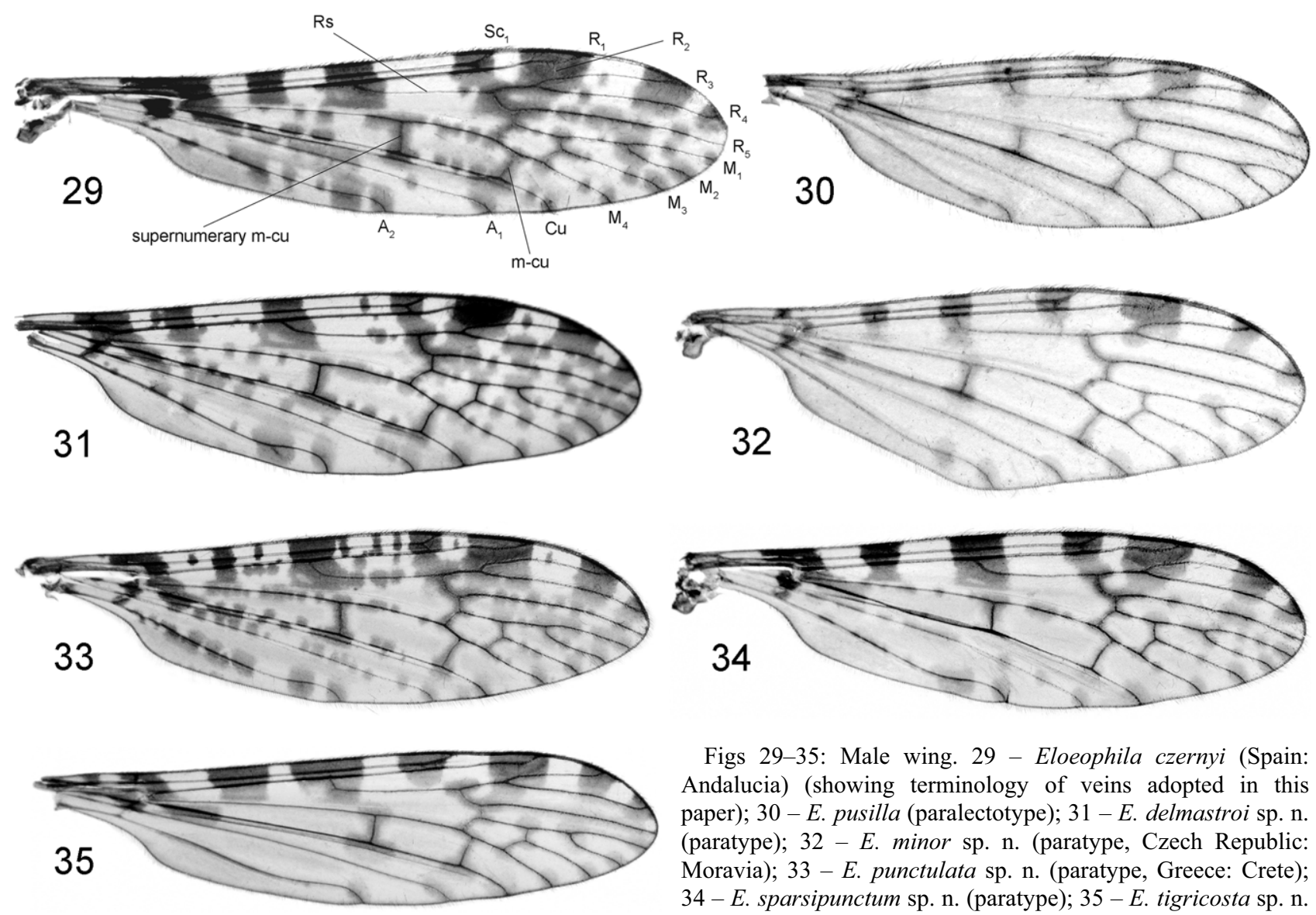

Figs 29-35: Male wing. 29 - Eloeophila czernyi (Spain: Andalucia) (showing terminology of veins adopted in this paper); $30-E$. pusilla (paralectotype); $31-E$. delmastroi sp. n. (paratype); $32-E$. minor sp. n. (paratype, Czech Republic: Moravia); $33-E$. punctulata sp. n. (paratype, Greece: Crete); $34-$ E. sparsipunctum sp. n. (paratype); $35-$ E. tigricosta sp. n. (paratype).

outer gonostylus with terminal spine small, aedeagus rather stout, moderate in length and apodeme of vesica short, finger-shaped. Wing length 7.0-9.4 mm.

Description. Male. Head. Antenna with flagellum obscure yellow, slightly darkened distally.

Thorax. Prescutum and scutum with pattern moderately distinct, median stripes long and entire, lateral stripes represented by fusion of several spots forming large irregular mark attached to median stripe anteriorly and extending to paratergite laterally; additional dotted line apparent between median and lateral stripe posteriorly, coinciding with row of setae. Wing (Fig. 34) moderately broad (about $1: 3.5$ ), with posterior margin evenly curved. Fork $\mathrm{M}_{1}-\mathrm{M}_{2}$ about twice as long as its petiole. Supernumerary m-cu opposite about one-third length of Rs and shortly before tip of $\mathrm{A}_{2}$. Wing with pattern dark brown, spots moderate in extent, anterior spots subequal in size to their interspaces, except for wide interspace between spots 3 and 4; additional markings on longitudinal veins, but none between anterior spots. Legs with femora obscure yellow, darkened at tips, darkening not especially broad and not intensive (cf. E. czernyi). Setae on legs rather long, nearly twice diameter of femur, but not as prominent as in E. czernyi.

Abdomen. Male terminalia (Figs 25, 26): Gonocoxite rather long and comparatively slender, enlarged at base and only slightly produced ventro-distally. Outer gonostylus with crest on outer margin distinct in certain views; terminal spine small; inner margin with subapical angle rounded and moderately pronounced. Paramere with

numerous setulae. Tip of lateral projection of lower shelf level with posterior edge of median projection. Aedeagus rather stout, moderate in length, distinctly exceeding tip of paramere. Vesica spherical, with apodeme short, finger-shaped.

Female resembling male in general appearance.

Type material. Holotype ot: Bulgaria, Pirin Mts, Lilianovo nr. Sandanski, 18.vi.1990 (J. Starý leg.) (SMOC). Paratypes (23 ऊิ, 3 q ): Bulgaria: Vitosha Mt., 20.v.1985, 1 ô (W. Krzemiński leg.); Rila Mts, Rilski Monastir, 26.vi.1982, 10 (W. Krzemiński leg.); Pirin Mts, Lilianovo nr. Sandanski, 9.v.1989,

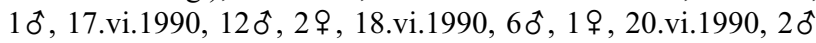
(J. Starý leg.) (all JSO).

Etymology. The name of this new species, sparsipunctum, a combination of sparsum (= scattered, sparse) and punctum (= the spot, dot), refers to the comparatively sparse additional markings on wing. A noun in nominative singular, standing in apposition to the generic name.

Distribution. Bulgaria.

Discussion. This species most closely resembles $E$. lucasi sp. n. in having comparatively few additional markings on longitudinal veins. Differences between this and the latter species are specified in the Discussion of $E$. lucasi $\mathrm{sp} . \mathrm{n}$.

\section{Eloeophila tigricosta sp. $\mathbf{n}$.}

(Figs 27, 28, 35)

Diagnosis. Comparatively large species within Eloeophila. Wing narrow, with only basic pattern. Male terminalia with outer gonostylus with terminal spine 
comparatively large, aedeagus slender, moderate in length and apodeme of vesica broad, rounded. Wing length 8.2-9.0 $\mathrm{mm}$.

Description. Male. Head. Antenna with flagellum entirely brown.

Thorax. Prescutum and scutum with pattern distinct, median stripes long, very broad, lateral stripes reduced to circular spot; another spot lateral to lateral stripe, close to paratergite. Wing (Fig. 35) narrow (about $1: 4$ ), with posterior margin evenly curved. Fork $\mathrm{M}_{1}-\mathrm{M}_{2}$ longer to subequal in length to its petiole. Supernumerary m-cu about opposite one-third length of Rs and level with or shortly beyond tip of $A_{2}$. Wing with only basic pattern, rather greyish brown or even blackish and rather extensive, anterior spots larger than their interspaces. Legs broken in both types.

Abdomen. Male terminalia (Figs 27, 28): Gonocoxite not especially long, rather stout, enlarged at base, only slightly produced ventro-distally. Outer gonostylus with crest on outer margin distinct in certain views; terminal spine comparatively large; wide subapical emargination on inner margin ending proximally in conspicuously rounded subapical angle. Paramere without setulae. Tip of lateral projection of lower shelf slightly exceeding posterior edge of paired sclerotized pincer-like structure of lower shelf, but membranous median projection of shelf narrowly extending beyond tip of lateral projection. Aedeagus slender, moderate in length, slightly exceeding tip of paramere. Vesica long-ovoid, with apodeme moderate in size, broad and rounded.

Female unknown.

Type material. Holotype $\delta$ : Spain, Castilla y Leon, Avila, Sierra de Gredos, Arenas de San Pedro $(550 \mathrm{~m})$, 15.v.-4.vi.1976, 1 đ (P. Oosterbroek \& E. Boersma leg.) (ZMAN). Paratype: $1 \delta^{\star}$, same data as for holotype (JSO).

Etymology. The compound name of this new species, tigricosta, fairly comprehensible as to the meaning of its components, refers to the banded appearance of the costal region of the wing caused by conspicuous anterior spots. A noun in nominative singular, standing in apposition to the generic name.

Distribution. Spain.

Discussion. This species is readily distinguished from the other species similar to $E$. verralli by the very large anterior spots on the wing that are larger than their interspaces (Fig. 35). Legs of both specimens are broken, but the femora are most probably gradually darkened towards tips, as they are in other species related to $E$. verralli. The structure of the male terminalia is somewhat similar to that of E. martinovskyi sp. n., differing especially in the length of the aedeagus (shorter in E. tigricosta sp. n.) and shape of the apodeme of the vesica, which is moderate in size and rounded in E. tigricosta sp. n. (large, fan-shaped in E. martinovskyi sp. n.) (cf. Figs 28 and 18).

ACKNOWLEDGEMENTS. For invaluable information and/or for the loan and gift of specimens, I am much indebted to the following: M. Chvála (Department of Zoology, Charles University, Prague, Czech Republic), G.B. Delmastro (Museo Civico di Storia Naturale, Carmagnola, Italy), A. Freitag (MZLS), J.-P. Haenni (Muséum d'histoire naturelle, Neuchâtel, Switzerland), U. Kallweit and B. Rulik (SMTD), J. Kramer (Leicester, Eng- land, UK), W. Krzemiński (Institute of Systematics and Evolution of Animals, Kraków, Poland), the late J. Martinovský (Olomouc, Czech Republic), the late H. Mendl (Kempten/Allgäu, Germany), P. Oosterbroek and the late Br. Theowald (ZMAN), P. Sehnal (NHMW), B.J. Sinclair (ZFMK), H.B. Williams and W.N. Mathis (USNM), and N.P. Wyatt (BMNH). F. Brodo (Ottawa, Canada) was the first to critically read a previous manuscript and kindly checked and improved the English. I thank J. Roháček (SMOC) and V. Bič (Univerzita Palackého, Olomouc, Czech Republic) for technical assistance. The work was supported by grant No. MSM6198959212 from the Czech Ministry of Education. The stay of the author at ZMAN was funded by project NL-TAF-736 of the Synthesys Programme.

\section{REFERENCES}

AleXANDER C.P. 1975: New or little-known crane flies from Iran. IV (Diptera: Tipulidae). J. N. Y. Entomol. Soc. 83: $129-138$.

Czerny L. \& Strobl G. 1909: Spanische Dipteren. III. Beitrag. Verh. Zool.-Bot. Ges. Wien 59: 121-301.

DiensKe J.W. 1987: An illustrated key to the genera and subgenera of the Western Palaearctic Limoniidae (Insecta: Diptera), including a description of the external morphology. Stuttg. Beitr. Naturk. (A) No. 409, 52 pp.

Edwards F.W. 1928: The Nematocerous Diptera of Corsica. Encyclopédie entomologique (sér. BII-Diptera) 4: 157-189.

EDWARDS F.W. 1938: British short-palped craneflies. Taxonomy of adults. Trans. Soc. Br. Entomol. 5: 1-168.

HeNNIG W. 1954: Flügelgeäder und System der Dipteren unter Berücksichtigung der aus dem Mesozoikum beschriebenen Fossilien. Beitr. Entomol. 4: 245-388.

Kuntze A. 1920: Eine neue Ephelia Schin. Dt. Entomol. Z. 1920: 56.

LACKSCHEWITZ P. 1940: Die paläarktischen Limnophilinen, Anisomerinen und Pediciinen (Diptera) des Wiener Naturhistorischen Museums. Ann. Naturh. Mus. Wien 50[1939]: 68-122.

LoEw H. 1871: Beschreibungen europäischer Dipteren. Zweiter Band. H.W. Schmidt, Halle, vii +320 pp.

MCALPINE J.F. 1981: Morphology and terminology - adults. In McAlpine J.F., Peterson B.V., Shewell G.E., Teskey H.J., Vockeroth J.R. \& Wood D.M. (eds): Manual of Nearctic Diptera 1. Research Branch, Agriculture Canada, Ottawa, Monograph No. 27, pp. 9-63.

MEIJERE J.C.H. DE 1921: Studien über palaearktische, vorwiegend holländische, Limnobiiden, insbesondere über ihre Kopulationsorgane (Schluss). Tijdschr. Entomol. 64: 54-118.

Oosterbroek P. 2008: Catalogue of the Craneflies of the World (Insecta, Diptera, Nematocera, Tipuloidea). Version 5 (online), March 2008 [http://ip30.eti.uva.nl/ccw/].

PierRe C. 1924: Tipulidae nouveaux. Encyclopédie entomologique (sér. BII-Diptera) 1: 79-93.

Podenas S., Geiger W., Mendl H., Stubbs A. \& Oosterbroek P. 1997: Limoniidae (Diptera, Nematocera) de Corse (France). Bull. Soc. Neuchât. Sci. Natur. 120: 161-168.

Reusch H. 1988: Faunistische und phänologische Untersuchungen über Stelzmücken des Niedersächsischen Tieflandes (Diptera: Limoniidae). Braunschw. Naturk. Schr. 3: 171-203.

SAVChenKo E.N. 1986: Limoniidae (Introduction, Pediciinae, Hexatominae): In: Fauna Ukrainy 14(2). Naukova Dumka, Kiev, 380 pp. [in Russian].

Savchenko E.N., Oosterbroek P. \& Starý J. 1992: Family Limoniidae. In Soós Á., Papp L. \& Oosterbroek P. (eds): Catalogue of Palaearctic Diptera, 1. Hungarian Natural History Museum, Budapest, pp. 183-369. 
StARÝ J. 1994: Revision of European species related to Tricyphona livida (Diptera: Pediciidae). Eur. J. Entomol. 91: 437-450.

STARÝ J. 2006: New information resulting from a study of Strobl's types of Limoniidae (Diptera). Acta Univ. Carol. (Biol.) 49[2005]: 187-203.

STARÝ J. 2007: Nomenclatural changes in West Palaearctic Limoniidae and Pediciidae (Diptera), II. Čas. Slezsk. Muz. Opava (A) 56: 23-36.
Starý J. \& Brodo F. 2009: Arctic species of the subgenus Symplecta s. str. (Diptera, Limoniidae). Can. Entomol. 141: 1-30.

Starý J. \& Reusch H. 2009: European species of the subgenus Brachylimnophila (Diptera: Limoniidae). Entomol. Fenn. 19[2008]: 207-217.

Received February 12, 2009; revised and accepted May 4, 2009 